Article

\title{
Wolf and Bear Depredation on Livestock in Northern Sweden 1827-2014: Combining History, Ecology and Interviews
}

\author{
Weronika Axelsson Linkowski ${ }^{1, *}$ (D), Marie Kvarnström ${ }^{1}$, Anna Westin ${ }^{1}$, Jon Moen ${ }^{2}$ \\ and Lars Östlund ${ }^{3}$ \\ 1 Swedish Biodiversity Centre, Swedish University of Agricultural Sciences, Box 7016, 75007 Uppsala, \\ Sweden; Marie.Kvarnstrom@slu.se (M.K.); Anna.Westin@slu.se (A.W.) \\ 2 Ecology and Environmental Sciences, Umeå University, 90187 Umeå, Sweden; jon.moen@umu.se \\ 3 Department of Forest Ecology and Management, Swedish University of Agricultural sciences, 90183 Umeå, \\ Sweden; Lars.Ostlund@slu.se \\ * Correspondence: Weronika.Axelsson.Linkowski@slu.se; Tel.: +46-18-672749
}

Received: 11 August 2017; Accepted: 11 September 2017; Published: 16 September 2017

\begin{abstract}
During the twenty-first century, large carnivores have increased in human dominated landscapes after being extinct or nearly extinct. This has resulted in increasing numbers of livestock killed by large carnivores. The intent of this paper is to give a land use-historical perspective on the recent livestock-carnivore conflict in boreal Sweden. More specifically we address: (1) depredation risks (livestock killed by carnivores) and (2) local knowledge of how to protect livestock from predation and whether it survived among pastoralists until the present. This study provides numeric information on carnivores, livestock and depredation, combined with oral information from summer farmers about livestock protection. We compare recent (since 1998) and historical (late nineteenth century) depredation rates in two Swedish counties. In Dalarna recent depredation rates are higher than historical rates while the opposite pattern is seen in Jämtland. Recent depredation rates in Dalarna are twice the recent rates in Jämtland, in contrast to the historical situation. Recent and historical depredation rates are of the same order. Summer farmers traditionally graze their livestock in forested areas where carnivores reside. Interviews show that traditional knowledge of how to protect livestock from carnivores was lost during the twentieth century, but recently new knowledge has developed leading to changes in summer farming practices. The carnivore-livestock situation today differs from the historical situation, not so much in levels of depredation, but mainly regarding the possibilities of farmers to face challenges associated with increasing carnivore populations.
\end{abstract}

Keywords: carnivores; livestock depredation; wolves; bears; traditional knowledge; summer farms

\section{Introduction}

As a result of management following national and international conventions, large carnivores have increased during the twenty-first century in human-dominated environments in Sweden [1,2] as well as in the rest of Europe [3]. As carnivores have increased [4-8], the numbers of livestock exposed and killed have also increased, affecting the conditions for livestock husbandry. The problem is not new. As far back as historical sources can confirm, carnivores have caused conflicts with livestock husbandry [9-11].

The recent and historical interactions between livestock, farmers and carnivores are complex. Before the introduction of fossil fuels and fertilizers, agriculture depended on a variety of ecosystem resources dispersed across the landscape. In Sweden, grazing mainly took place in wooded pastures, semi-natural environments composed of natural vegetation but shaped by livestock grazing and other 
human uses such as wood cutting [12]. The grazing was also dependent on and shaped by natural conditions in the pasture. Thus, human-nature relationships are reciprocal, meaning that human land use is shaped by and is also shaping the environmental resource, and therefore it is necessary to apply an historical ecological approach to fully understand the complexity of this relationship [13]. In many parts of Sweden (as well as in other European countries) co-existence between humans and large carnivores is problematic, because of competition for the livestock. Therefore, the farmers must have knowledge and means to protect their livestock from depredation.

The intent of this paper is to give a land use historical perspective on the recent livestock-carnivore conflict in boreal Sweden. The effects of carnivore recolonization can be expected to be particularly evident at summer farms, because livestock grazing in unfenced forest during the summer are particularly exposed to carnivores. Our study area is the neighboring counties of Jämtland (c. 49,000 km²) and Dalarna (c. 28,000 km²), in northern Sweden, where carnivores have recolonized and where summer farms still exist (Figure 1). We focus on the effects of bears and wolves as they are the carnivores responsible for a large proportion of the depredation of livestock in Sweden.

The main components of the addressed problem, i.e., livestock husbandry, carnivores, farmers and the means by which they can handle the carnivore threat, will be introduced more in detail before turning to the used methodology.

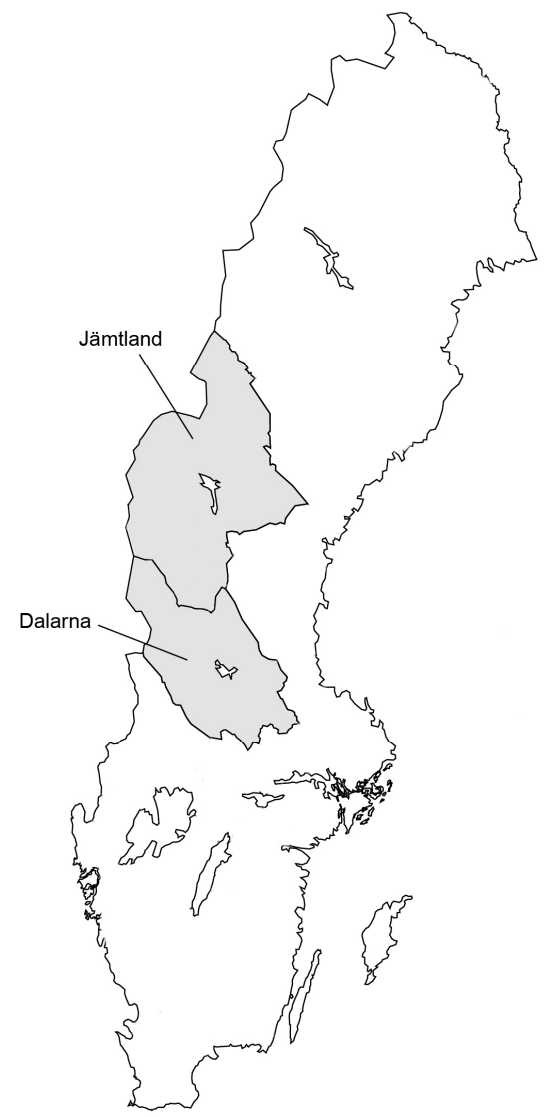

Figure 1. The location of the studied Swedish counties Dalarna and Jämtland.

\subsection{Summer Farming in Sweden}

The northern and central parts of Sweden are part of the boreal coniferous Western Taiga, a primarily forested landscape. Here local, pre-industrial subsistence has mainly been focused on animal husbandry due to prevailing climatic and other biophysical conditions [14]. Historically, grazed forests were widespread and livestock were moved between the home farms and summer farms, 
in order to access remote grazing grounds during the summer months [11,12], to increase the total available grazing grounds, and to enable pastures close to the home farm to regrow before late summer grazing [12,14-16]. This transhumance system (Sw. fäbodbruk) existed at least since the sixteenth century [16], and reached its height in the 1850s. All villages in the summer farming districts had access to at least one summer farm, and each summer farm was often used by several villages. The Swedish forests harbored large numbers of free ranging livestock that spent a large portion of the grazing season (1 June to 31 October) on forested land [12]. Summer farming created a characteristic and complex anthropogenic landscape (Figure 2). Cows (Bos taurus taurus), sheep (Ovis aries), goats (Capra hircus) and occasionally horses (Equus caballus) were herded, often by young girls in groups of two to three, to steer them to patches with good grazing and away from hay harvesting areas, but also to scare off carnivores and livestock thieves. One important aspect is that the herders were not expected to track down and kill carnivores [9,17]. Hides and milk products such as butter and cheese were important sources of income for the farmers [16].

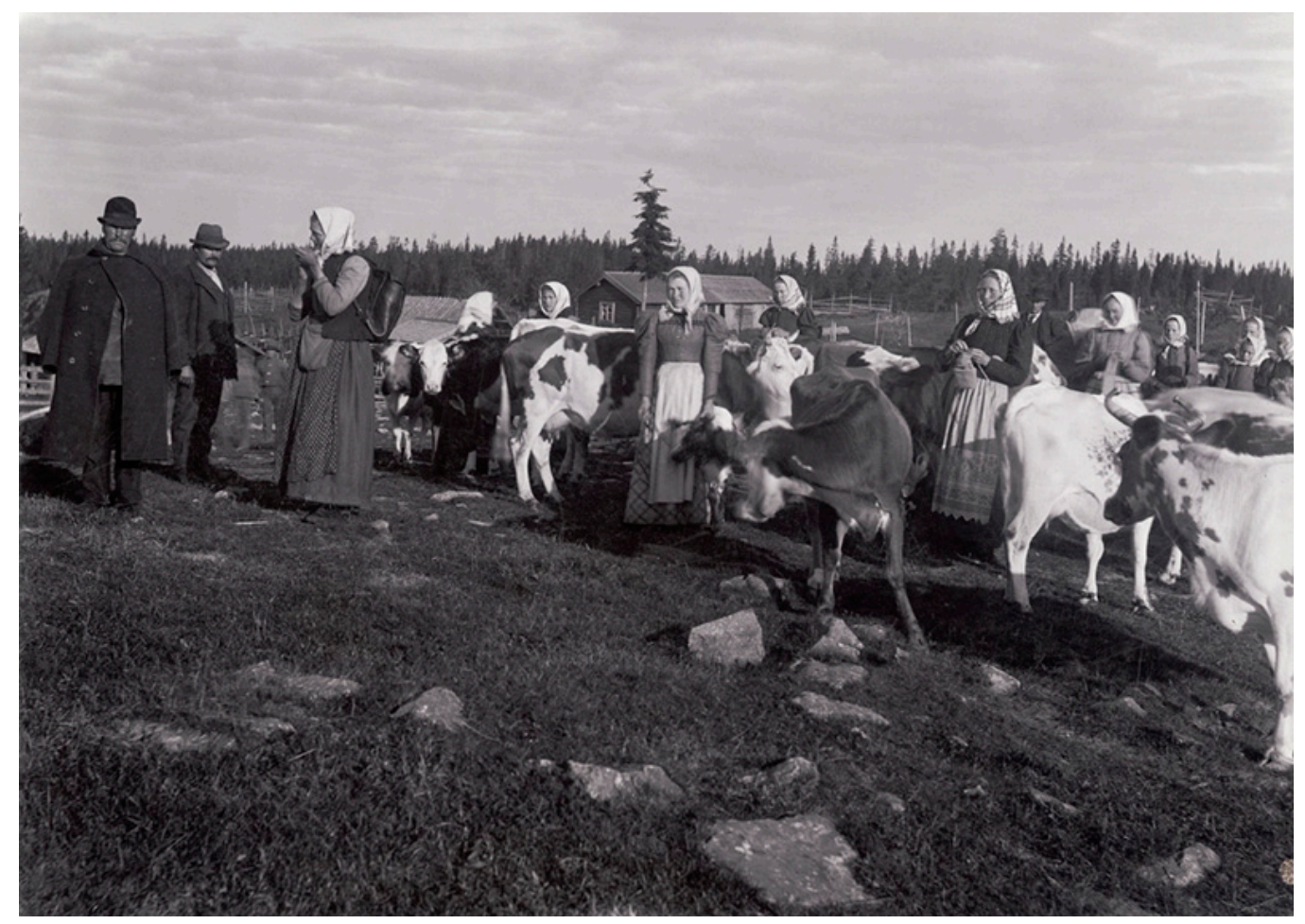

Figure 2. Nyckelberg summer farm in Malung, county of Dalarna, in the year of 1901. Note the open intensively grazed environment at the time, the female herders and visiting men. Photographer unknown. Nordiska Museet, Public Domain.

From the 1870s, summer farming decreased rapidly due to agricultural changes, including cultivation of fodder on arable land in the village which provided better fodder for the new breeds compared to low productive forest pastures [16]. From 1920 and in the following decades the Swedish forest companies also worked hard to reduce the livestock grazing in forest land [12]. In 2012, there were 201 registered summer farmers, eighty of them in the county Dalarna and eighty in the county Jämtland (neighboring north of the county Dalarna) [18] (Figure 3). Today summer farmers can receive agri-environmental payments through the Swedish Rural Development Program for 2014-2020, with the aim of supporting summer farming that "strengthens and preserves the character of the landscape and its biological diversity" [19]. Without grazing, mountain and boreal forest biodiversity dependent on this activity will decline [20-23], and associated grazing dependent cultural values will be lost $[24,25]$. 


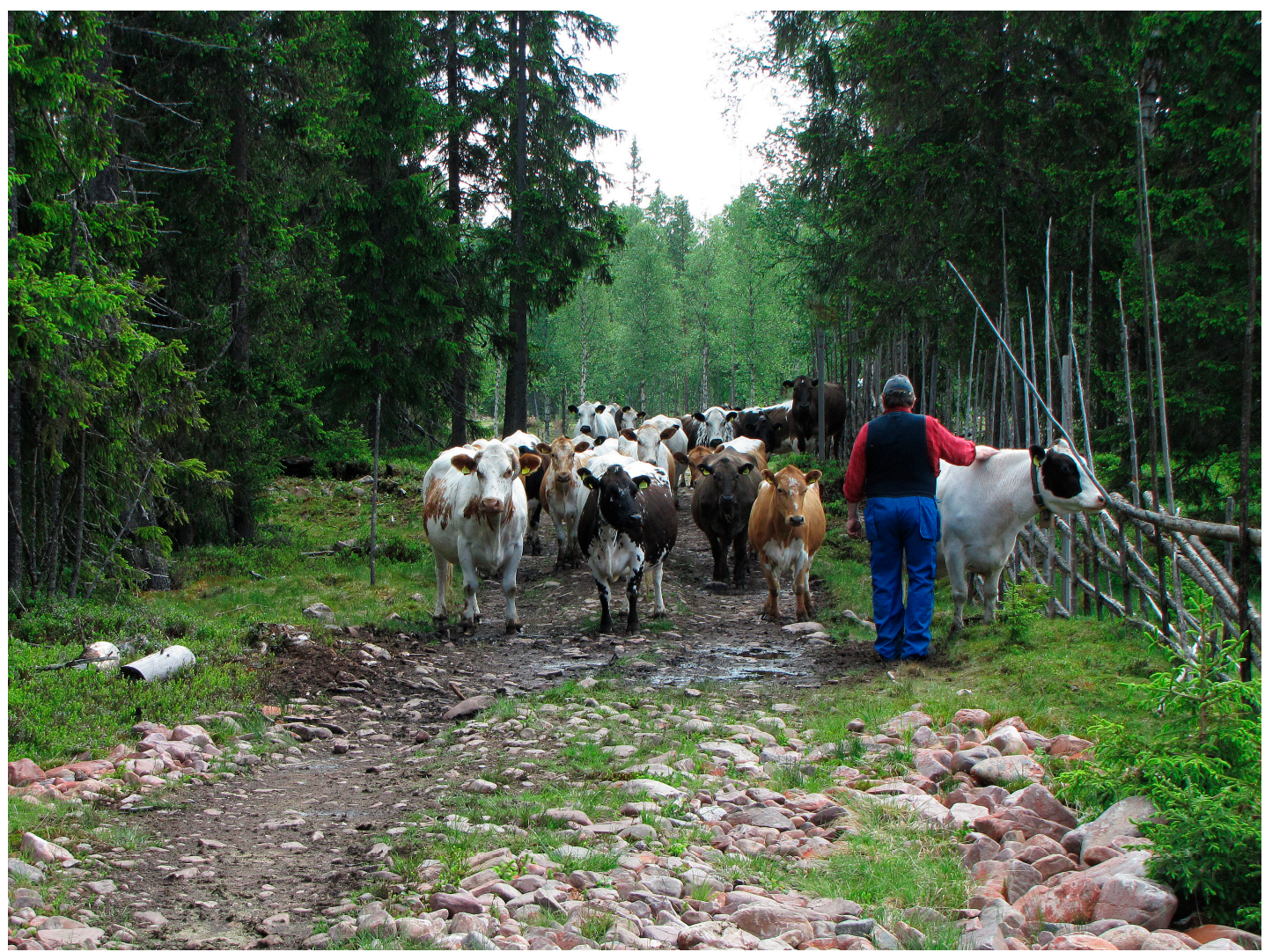

Figure 3. Vålbrändan summer farm in the county of Dalarna, in the year of 2011. Now the forest is denser around the summer farms due to reforestation in recent years. Photographer: Tommy Lennartsson.

\subsection{Carnivores in Sweden}

The large carnivores in Sweden are bears (Ursus arctos), wolves (Canis lupus), Eurasian lynx (Lynx lynx) and wolverine (Gulo gulo). Fennoscandia is the only region in Europe where all four species can be found. Carnivores colonized the Scandinavian Peninsula around 10,000 years ago, after the last glaciation, at the same time as humans. Bears, lynx and wolverines live solitary lives, hold territories and only meet to mate. Bears often get 1-2 young, lynx up to four and wolverine up to five pups. Young wolves appear as solitary and often wander long distances for a new territory and/or a partner. When they meet a partner they form a territory holding couple. Mating often results in 4-8 pups which together with their parents form a pack, as the young stay with their parents for some years [26].

Humans and carnivores have always competed for livestock, but humans have also hunted the carnivores for their furs. As humans became more dependent on livestock farming and reindeer herding, organized carnivore hunting started [17]. During the nineteenth century, hunting led to reduced numbers of carnivores in Sweden and started a debate about the cruelty against carnivores and the necessity to protect them $[27,28]$. During the twentieth century, large carnivores gained legal protection from being hunted, after which the populations increased in Sweden and Europe, although with a time-lag (in Sweden the lynx gained protection in 1928 and the wolverine 1969) $[3,29,30]$.

When the bear became a protected species in 1927, it was close to extinction, with an estimated 130 animals left in Sweden [31]. In Dalarna, the bear became functionally extinct in 1897, but this was never the case in Jämtland [31]. Since the 1990s the bear population has increased and bears are now commonly found in Sweden from Dalarna northwards [32].

The last bounty paid for wolves was in 1965 and already the following year the wolf became a protected species [2,33]. At that time there were 20-40 wolves left, mainly in the mountain areas in northern Sweden [33]. With around 10 wolves left in the 1970s, the species was regarded as functionally 
extinct in Sweden. The first known wolf reproduction events after being protected occurred in 1989 and 1991, and subsequently the wolf population has increased $[33,34]$. The wolf has its reproductive center in the southern part of the boreal region, in the counties Dalarna and Värmland [35]. Further north in the county Jämtland, no resident wolves are allowed since reindeer herding is considered a national interest and since reindeer are also very exposed to carnivores because they graze outdoors all year around [36,37].

A strongly restricted annual bear hunt started in 1943 [38], and a similar wolf hunt in 2010 [3]. It is also possible to receive permission for protective hunting of carnivores that cause damage to livestock. Such permission is controlled by the county administration boards.

\subsection{Carnivores, Livestock, Local and Traditional Knowledge}

The risk of exposing grazing livestock to carnivores was historically mitigated by a combination of protecting livestock and reducing carnivore populations [10,11,33,39]. There was a range of practices aimed at protecting livestock from carnivores in Sweden. In the Middle Ages, herding was primarily taken done by grown up men equipped with dogs who could protect the herd. Later the task of herding was taken over by women and children but without dogs [11]. In Sweden, the reduction of large carnivores though hunting was sanctioned by the crown, and there is documentation pertaining to bounty payments with the purpose of reducing injuries on livestock from 1647 to 1965 [17]. Several methods of hunting were used, e.g., mandatory drives to drive wolves towards traps and killing sites, poisoning and finding the dens where the pups could be killed. Before the grazing season started, it was common for villagers to assemble to scare carnivores away from the grazing grounds with noise and fires. If carnivores came, the herders tried to scare them off and were also expected to call for help from others. Important tasks were keeping the livestock assembled and under constant watch, being alert to any change in behavior that could indicate presence of carnivores and directing livestock to safer grounds [9]. It is important to note that since the herders did not hunt or kill the carnivores themselves, the knowledge handed down between generations of summer farmers cannot be expected to include knowledge about tracking and killing carnivores. Knowledge about hunting carnivores was instead held by male adult villagers.

The herding practices indicate the use of practical experience-based knowledge, not only about handling livestock and knowing the grazing grounds, but also about the behavior of carnivores and how to protect the livestock [5,7,40-42]. Ethnological initiatives from the early twentieth century have contributed to the written documentation of such knowledge in Sweden $[9,43]$. This local and "traditional ecological knowledge" (TEK) is defined as a "cumulative body of knowledge, practice and beliefs, evolving by adaptive processes and handed down through generations by cultural transmissions, about the relation of living beings (including humans) with one another and the environment" [44]. Often the term "local and traditional knowledge" is used, emphasizing the place-based nature of the knowledge $[45,46]$. The ecological aspect of the knowledge helps people to make a living in the local environment and adapt to changing conditions. The knowledge itself is adaptive, meaning that people maintain and develop knowledge that is needed, while knowledge that is no longer needed becomes obsolete. At summer farms with an unbroken tradition of keeping livestock, the knowledge complex on taking care of livestock, maintaining the grazing grounds and processing milk has been in continuous use. However, like the practices of Hungarian [41,42] and Spanish $[24,47,48]$ sheep herders, the knowledge of Swedish summer farmers has also constantly adapted to changing socio-ecological environments. Carnivores represent one such changing environmental condition. From being numerous they decreased during the nineteenth century, became nearly extinct and came back again during the twentieth century. Even though the carnivores themselves were functionally extinct, the stories were alive in people's minds long after [9]. It remains to be found out if the risk of carnivore encounters and damage were enough to sustain knowledge about protective measures locally. 
When the carnivore populations increased in the 1990s, summer farmers in the counties of Dalarna and Jämtland were the first to experience their impact. Today these counties have the largest share of bear attacks on livestock in Sweden [38].

\subsection{Research Questions}

The recent increase in carnivore exposure, after about a century with no or few carnivores, demands retrospective studies placing the recent livestock-carnivore interactions in a historical perspective.

There are Swedish studies on the development of carnivore populations $[10,27,28,31-33,35]$, and on changes in the number of livestock [14]. However, there are no studies prior to this one that combine number of carnivores and livestock, with data on livestock killed by carnivores (depredation) over a long period. Studies on the knowledge required to handle the presence of carnivores are also needed in order to increase our understanding of how human-carnivore coexistence can be facilitated though practical measures [5,7].

Such complex problems are best resolved using methods and sources both from humanities and biological sciences with the deliberate intention of constructing long and well-founded perspectives on present day environmental problems $[13,49]$. Specifically we address the following questions:

(1) How has the risk of depredation (livestock killed by carnivores) changed since the second half of the nineteenth century?

And

(2) Has local and traditional knowledge of how to protect livestock from predation survived until the present?

\section{Materials and Methods}

\subsection{Number of Carnivores}

There are no historical records of the total number of carnivores in Sweden; hence we used the numbers of wolves and bears killed as proxy estimates of the total numbers of carnivores. Drives against carnivores were mandatory in Sweden since the Middle Ages. In 1647, bounties were introduced and from 1827 there is official data on carnivores killed based on applications and payments of bounties for hunted, poisoned and trapped carnivores and also pups killed at dens $[9,17,27,28]$. Historical data on bears and wolves killed in Jämtland and Dalarna were compiled for the years 1827 to 1910 from the Swedish National Forest Service [50] and from 1911 to 1965 from the Royal Forest Service administration [51]. The origin of the data can be followed in sources consisting of applications for the disbursement of bounties with testimonials from the parish where wolves were killed and receipts on bounties paid from 1822 to 1859 [10]. A source critical analysis shows that this data should be trustworthy because the Forest service had a very efficient administration and also foresters working at the local level with good insight into the local communities. Also there were good incentives for the hunter to come forward with all killed carnivores since they actually got paid for each animal. The inspectors at "häradsnämnden" (the official board of the local administrative unit) limited the risk of double payment of wolves through collecting the ears of the killed animal. It is thus likely that the data are accurate when it comes to the number of killed carnivores in each county. However, we cannot totally exclude the possibility that the killing data present an underestimation of the real numbers.

Time series of killed wolves, wolverine and lynx have been presented, thoroughly commented on and used as proxies for population development of carnivore populations at the national or larger level in the Nordic countries [28,52,53].

Records of the total number of wolves are available from the winter of 1998/1999 at the Wildlife Damage Centre [54]. Based on this data, we counted the number of wolf packs and wolf pairs residing in Jämtland and Dalarna, until the winter of 2014/2015. When a pack or a wolf pair was shared with a neighboring county, we counted it as a half in each county, and if the pack was divided between 
three counties we counted it as 0.3 [34]. To get an estimate of population numbers, we multiplied the number of wolf packs by six and the number of wolf pairs by two [2]. The county administration boards of Dalarna and Jämtland provided data on bear populations: in Dalarna from 2004 to 2013 and in Jämtland from 2006 to 2014. The historic period refers to the time before the protection of carnivores (ca. 1965), and the recent period starts at their return (approx. 1998). Although these data series are not directly comparable, they provide the best possible estimates on population changes.

\subsection{Numbers of Livestock}

Numbers on cattle, horses, sheep and goats were collected from official data for the period 1865 to 2014. From 1865 to 1911, the Regional Agricultural Societies (Sw: Hushållningssällskap) delivered yearly reports on livestock numbers in each county [55]. During the period 1913 to 1919, Statistics Sweden undertook local surveys, while between 1927 and 1964 the data rely on information provided by farmers every five years [56]. From 1965 to 2001 we used yearly data from the Statistical Yearbook of Agriculture [57] and from 2001 to 2014 we used the Yearbook of Agricultural Statistics [58]. A source critical analysis of this material shows that the data on livestock numbers are highly reliable at the county level already in 1865 . The Regional Agricultural Societies who were responsible for reporting agricultural data had regular contact with local farmers and a good insight into their region. If information was missing from parts of the county, this was reported and corrected the following year. The method was replaced in 1913 because it was very time consuming for the Regional Agricultural Societies.

\subsection{Depredation on Livestock 1876-1930 and 1999-2014}

Data on depredation of livestock were collected from the official statistics from the Swedish National Forest Service [50,51] for the years 1876 to 1930, after which this information was no longer recorded in the Swedish official statistics. The primary data was collected by the efficient administration of the County Administration Boards. There was a national economic interest in livestock production and therefore the authorities wanted clear and accurate information about the problem of depredated livestock. The economic value of the killed livestock was estimated per county. No payments were made to the farmers but the need for economic compensation to the farmers was raised at regular intervals in the descriptions following the estimations of the economic values of killed livestock [50,51].

In 2003 the Wildlife Damage Centre started to publish yearly statistics on numbers of depredated livestock [59]. From the Wildlife Damage Centre we also gained access to unpublished data for the years 1999 to 2002. We used information on attacks on cattle, sheep, and goats and on the carnivore species responsible for the attacks, all for the years 1999 to 2014.

For comparison the annual means number of cattle, goats and sheep were calculated for the periods 1876 to 1930 and 1999-2014 and also the proportion of cattle, goats, and sheep killed of the total number of livestock depredated.

Depredation averages for cattle and sheep were calculated (the numbers of depredated livestock divided by the total number of livestock) for two separate time periods. The period 1876-1891 represents a time when livestock were abundant and strenuous efforts were made to hunt carnivores. The other period, 1999-2014, represents a time of increasing numbers of carnivores and a stable number of livestock.

\subsection{Interviews with Summer Farmers}

In order to study available local and traditional knowledge about protection against carnivores, we conducted semi-structured interviews with active or recently active summer farmers who had experiences of carnivore encounters at their summer farms, and who were known to us from previous work [25]. In all twelve farmers, four from Jämtland and eight from Dalarna, were interviewed over the phone or in the field. At the time of our interviews, there were approximately 160 summer farmers registered in Jämtland and Dalarna ( 80 in each county). The farmers interviewed thus constituted 
around 7.5 per cent of the total. Five of the farmers were female, seven were male. The summer farmers interviewed were selected because of their early and/or frequent experience of encounters with carnivores, i.e., we searched for farmers who were among the first to experience the increase in carnivores.

We used open-ended questions about carnivore attacks and experiences and knowledge of how to protect the livestock. We specifically asked for knowledge passed on from previously active farmers in order to document transmitted knowledge about carnivore and livestock encounters. The specific questions included: pastoral history of the summer farm including history of predation, predominant occupation of the farmer, kinds and numbers of livestock kept, kinds of products and values produced at summer farm, ways of gaining personal knowledge of prevention of predation, knowledge of prevention of predation other than own knowledge, awareness of written sources of information on carnivore prevention, personal history of encounters with carnivores at the summer farm, including livestock injuries and deaths, livestock behavior and movements at and after carnivore contact, changes in carnivore behavior, preventive measures undertaken against carnivores, consequences of carnivores presence and proposals for carnivore management.

The interviews were analyzed with a focus on which carnivore was responsible for the attacks, what livestock were attacked, behavior of livestock and carnivores, farmers' knowledge of how to protect their livestock, where the knowledge came from and proposals for future management.

\section{Results}

\subsection{Number of Carnivores}

The number of wolves killed annually fluctuated during the study period 1827-1965, with some notable differences between Jämtland and Dalarna. In total, more wolves were killed in Jämtland (1309, compared to 673 in Dalarna). In Jämtland, the wolf hunts continued by several decades longer than the hunts in Dalarna, where the number of wolves killed decreased earlier and where the last wolf was killed as early as 1916, compared to 1965 in Jämtland (Figures 4 and 5).

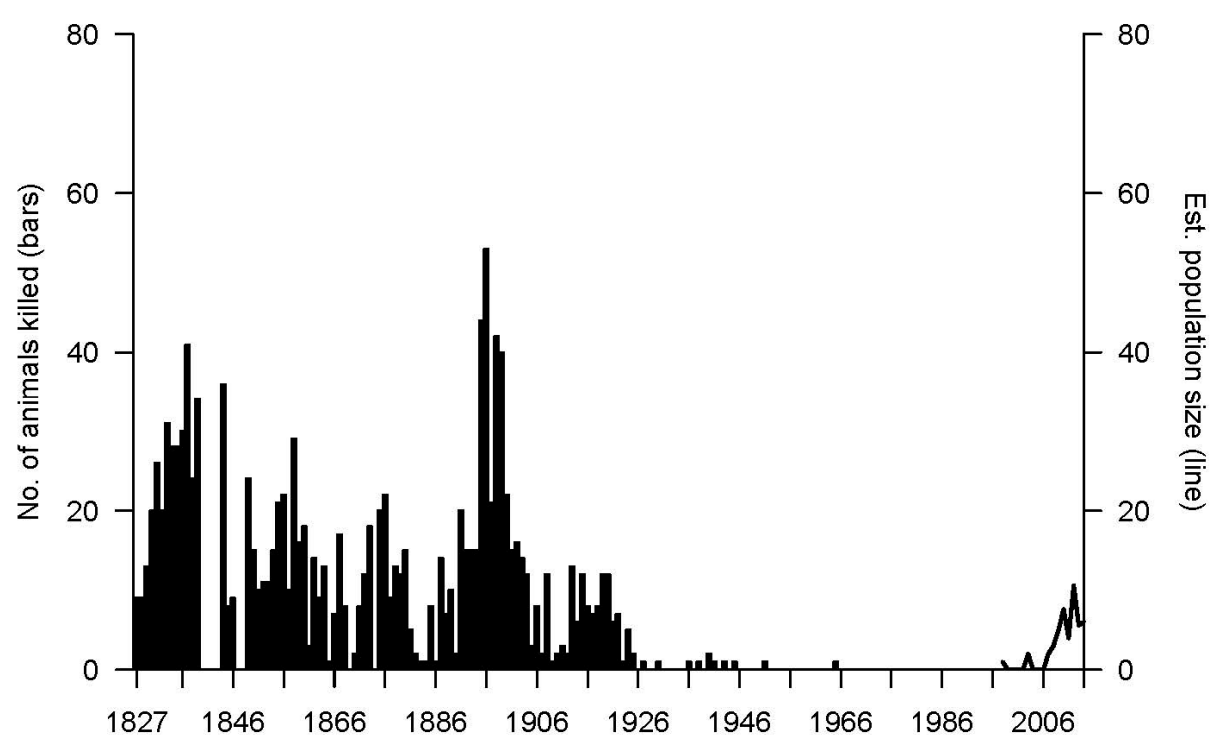

Figure 4. Number of wolves killed 1827-1965 (no data available for 1840-1843 and 1847-1848) in Jämtland (bars). Wolf population size based on yearly winter counts 1998/1999-2014/2015 in Jämtland (line). Sources: Swedish National Forest Service and Wildlife Damage Centre. Please note that the bounty data end in 1965 and winter counts start in the winter1998/1999. 


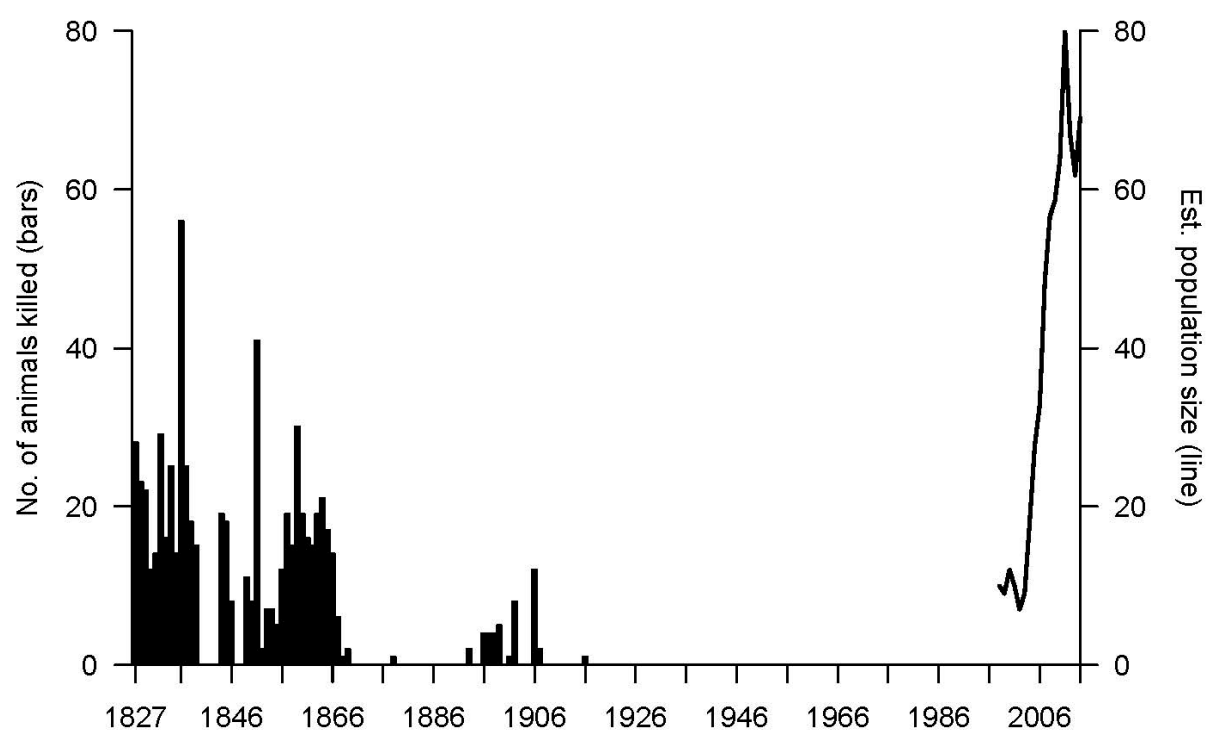

Figure 5. Number of wolves killed 1827-1965 (no data available for 1840-1843 and 1847-1848) in Dalarna (bars). Wolf population size based on yearly winter counts 1998/1999-2014/2015 in Dalarna (line). Source: Swedish National Forest Service and Wildlife Damage Centre. Please note that the bounty data end in 1965 and winter counts start in the winter1998/1999.

The wolf population in Dalarna was estimated to 10 individuals when the monitoring started in 1998/1999. After 2004, the population increased rapidly, reaching 80 individuals in 2011 (Figure 5). The population in Jämtland was smaller and had not exceeded 11 individuals by 2012 (Figure 4).

In addition, the total number of bears killed was also larger in Jämtland (1548 compared to 1035 in Dalarna, Figures 6 and 7). In Jämtland the highest number of bears was approximately 1000 and in Dalarna 500 in the later period.

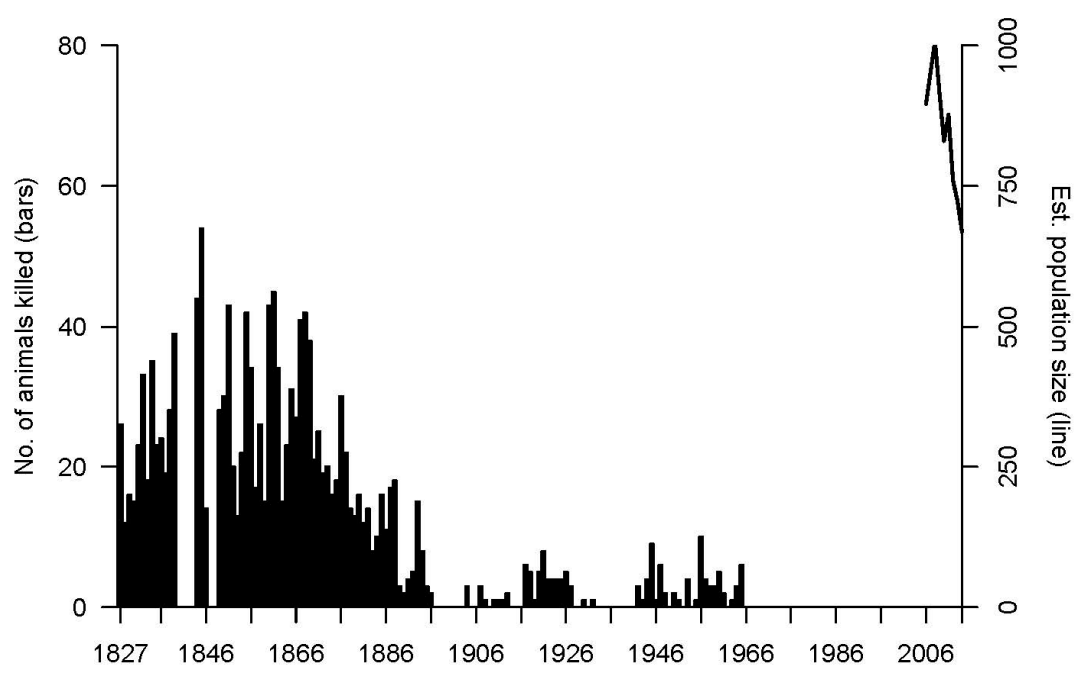

Figure 6. Number of bears killed 1827 to 1965 (no data available for 1840-1843 and 1847-1848) in Jämtland (bars). Estimated population size of bears from 2006-2014 in Jämtland (line). Sources: Swedish National Forest Service and the County Boards of Jämtland. Please note the different scales on the $\mathrm{y}$-axes and that the bounty data end in 1965 and population estimates start in 2006. 


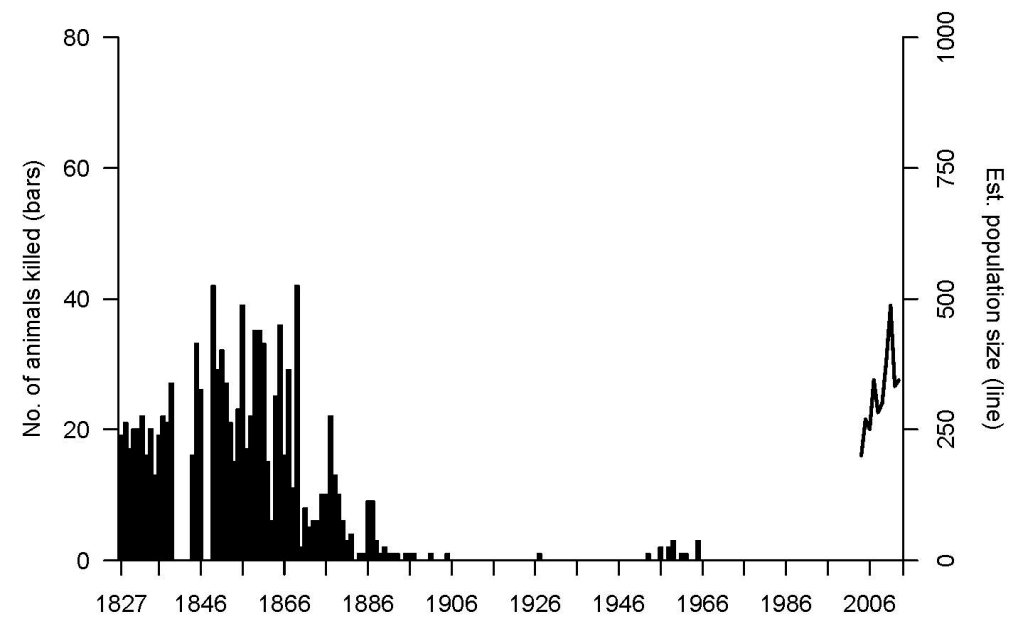

Figure 7. Number of bears killed 1827-1965 (no data available for 1840-1843 and 1847-1848) in Dalarna (bars). Estimated population size of bears 2004-2013 in Dalarna (line). Sources: Swedish National Forest Service and the County Boards of Dalarna. Please note the different scales on the y-axes and that the bounty data end in 1965 and population estimates start in 2004.

\subsection{Number of Livestock}

The general changes in livestock numbers were similar in Dalarna and Jämtland (Figures 8 and 9). We can distinguish three time periods. (I) The period from 1865 to 1919 is characterized by an increase in the number of cattle and a decrease in the number of sheep and goats. This shift is in line with the general trend in Sweden. The increased demand for milk, together with the development of more productive breeds, encouraged farmers to increase the number of cows. At the same time, the profitability of products from sheep and goats decreased. During the World Wars, the number of sheep and goats generally increased temporarily [60]; (II) during the period 1919-1970, the number of cattle and sheep declined to the levels that have remained, with some variation, until the present. The decrease in number of cattle in the post-war period agrees with the national trend, which corresponds with a general decrease in the number of farms that kept cattle [61]. The number of goats reached a very low level in 1947, after which goats disappeared from the statistics; (III) from 1965 to 2014, there was a small but steady reduction in the number of cattle in Jämtland and Dalarna. The numbers of sheep were stable in Jämtland and increased slightly in Dalarna.

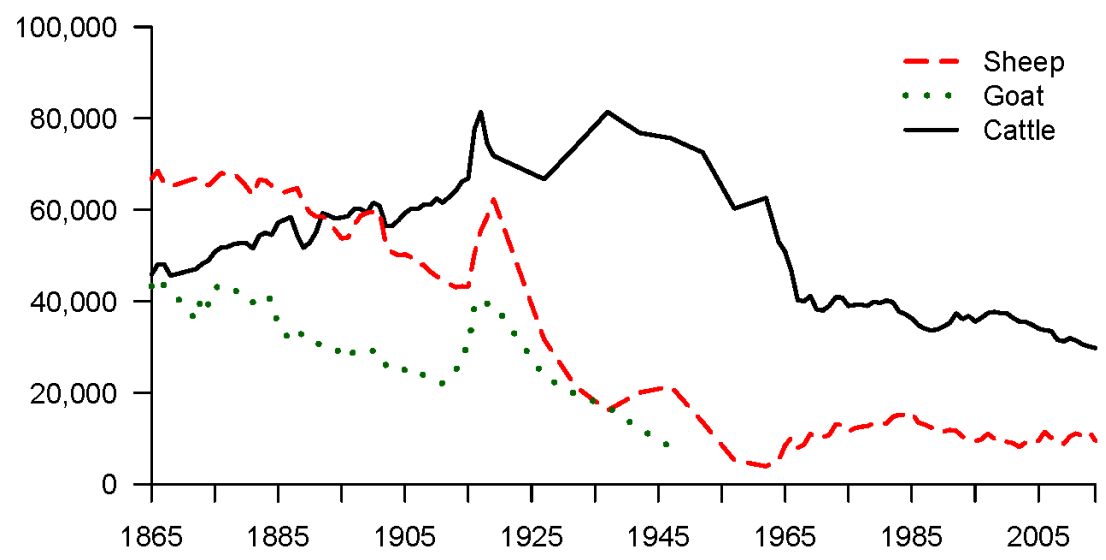

Figure 8. Illustration of the change in number of cattle, sheep and goats in Jämtland, from 1865 until 2014. From 1947 onward there are no records on the number of goats. Solid black line represents cattle, red dashed line represents sheep and green dotted line represents goats. Sources: Regional Agricultural Societies and Statistics Sweden. 


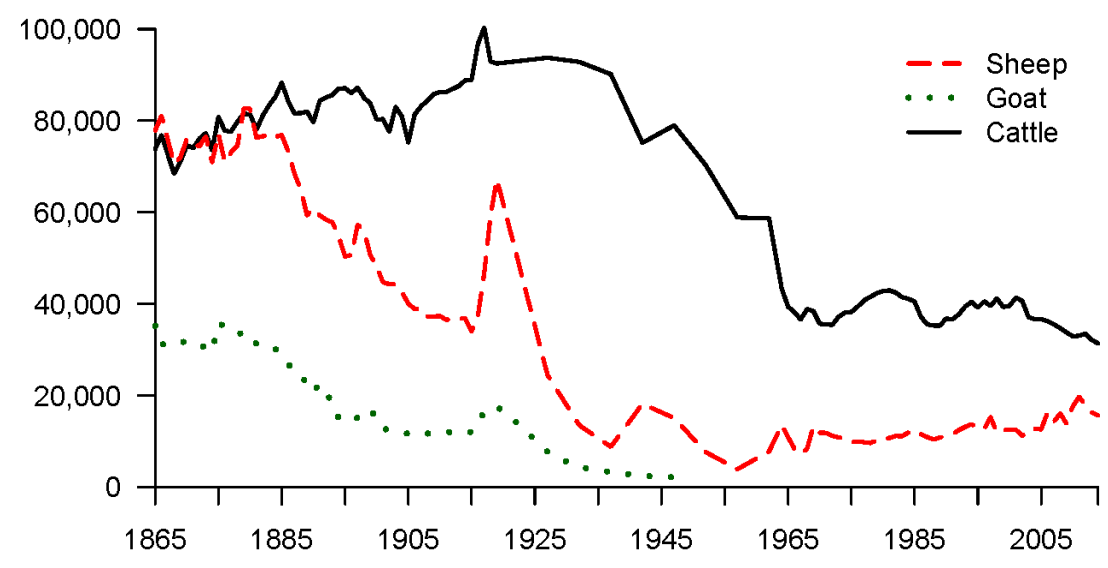

Figure 9. Illustration of the change in number of cattle, sheep and goats in Dalarna, from 1865 until 2014. From 1947 onward there are no records on the number of goats. Solid black line represents cattle, red dashed line represent sheep and green dotted line represents goats. Sources: Regional Agricultural Societies and Statistics Sweden.

\subsection{Depredation on Livestock, $1876-1930$ and 1999-2014}

Historical depredation of cattle, goats and sheep in Jämtland was higher than recent depredation and higher than both historical and recent depredation in Dalarna, with the exception of annual number of cattle depredated in Dalarna in 1999-2014 (Table 1). There, the annual mean is 3.1 cattle per year. Sheep were the livestock most frequently attacked throughout the studied time periods in both counties (Figures 10 and 11, Table 1).

In Jämtland, most of the livestock during the last 16 years were killed by bears (18 cattle and 203 sheep, compared to 3 cattle and 66 sheep killed by wolves). In Dalarna most of the livestock were killed by wolves (24 cattle and 529 sheep, compared to 18 cattle and 312 sheep killed by bears).

The average depredation rate was about three times higher in Jämtland compared to Dalarna during the late nineteenth century. Since the return of the carnivores, the situation is reversed and there is a larger proportion of the livestock killed in Dalarna than in Jämtland (double for cattle and 1.5 times for sheep, Table 2).

The depredation rate of cattle in Jämtland in the period 1999 to 2014 was less than half that in the late nineteenth century, while sheep in Jämtland were depredated at almost the same rate during the two periods (Table 2). In contrast, in Dalarna the rate of cattle and sheep being killed by carnivores during recent years is almost three and four times higher, respectively, compared to figures from the end of the nineteenth century.

Table 1. Total number of depredated cattle, goats and sheep, during the two periods 1876 to 1930 and 1999 to 2014 . The average of depredated animals per year was also calculated as the total number of depredated livestock divided by the length of the time period.

\begin{tabular}{ccccccc}
\hline County & \multicolumn{3}{c}{ Jämtland } & \multicolumn{3}{c}{ Dalarna } \\
\hline Year & Cattle & Goats & Sheep & Cattle & Goats & Sheep \\
\hline 1876-1930 & 121 & 708 & 8205 & 45 & 183 & 2182 \\
Annual mean & 1.9 & 10.9 & 126.2 & 0.7 & 2.8 & 33.6 \\
\hline 1999-2014 & 23 & 5 & 421 & 47 & 11 & 1021 \\
Annual mean & 1.5 & 0.3 & 28.1 & 3.1 & 0.7 & 68.1 \\
\hline
\end{tabular}




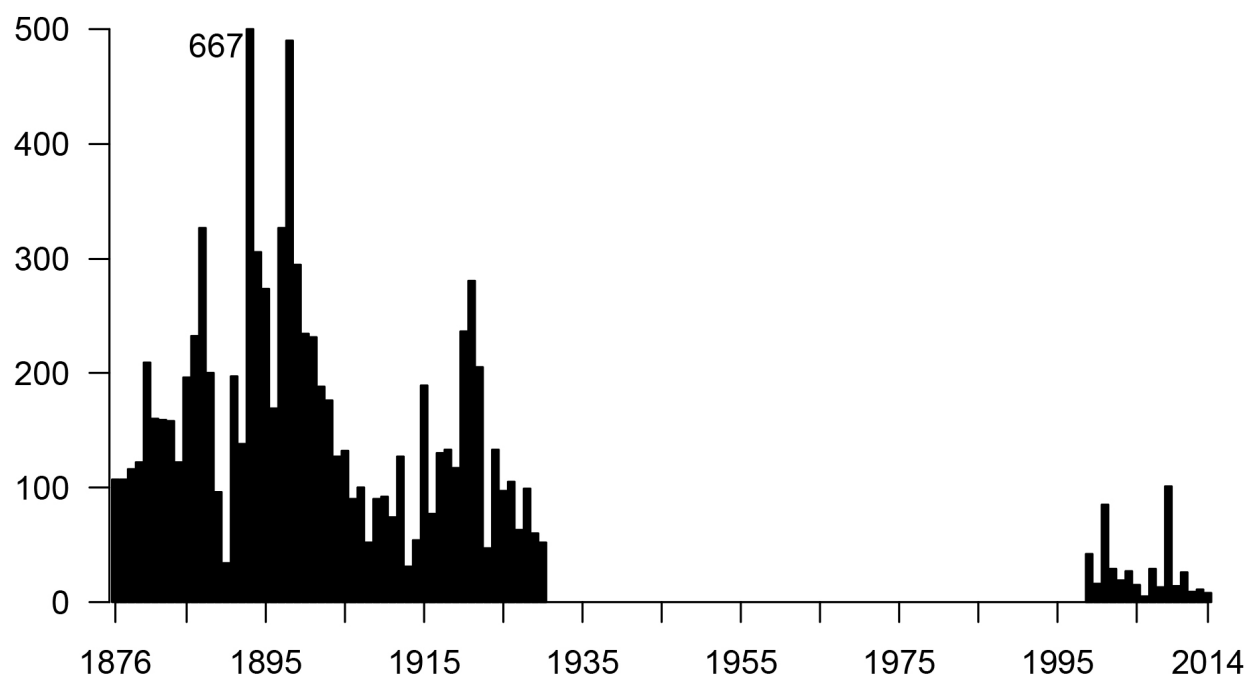

Figure 10. Illustration of the total number of livestock depredated by carnivores per year, 1876-1930 and 1998-2014, in the county of Jämtland. Sources: Swedish National Forest Service and the Wildlife Damage Centre. Please note that there are no records of livestock killed for the years 1931 to 1998.

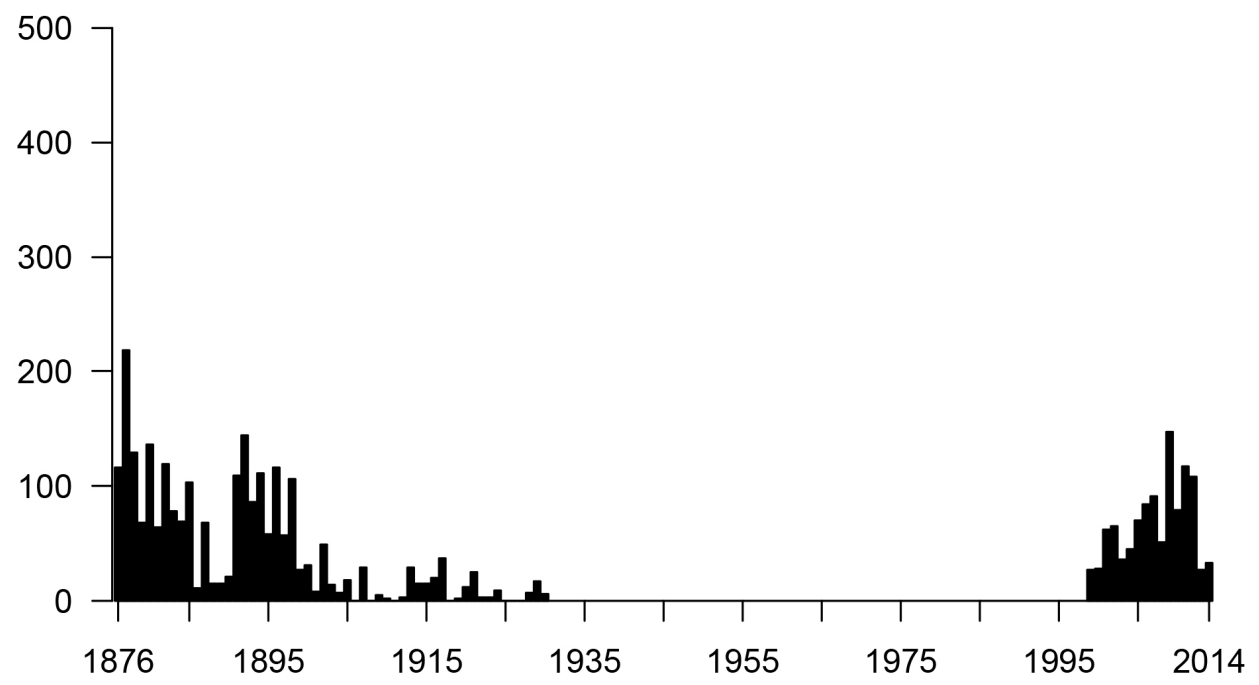

Figure 11. Illustration of the total number of livestock depredated by carnivores per year, 1876-1930 and 1998-2014, in the county of Dalarna. Sources: Swedish National Forest Service and the Wildlife Damage Centre. Please note that there are no records of livestock killed for the years 1931 to 1998.

Table 2. The average depredation rates in Jämtland and Dalarna for cattle and sheep (the numbers of depredated animals divided by the total number of livestock). Two separate time periods: 1876-1891 represents the historical time when livestock were abundant and strenuous efforts were made to hunt carnivores, while the recent period, 1999-2014, represents increasing numbers of carnivores and a stable number of livestock.

\begin{tabular}{ccccc}
\hline County & \multicolumn{2}{c}{ Jämtland } & \multicolumn{2}{c}{ Dalarna } \\
\hline Year & Cattle & Sheep & Cattle & Sheep \\
\hline $1876-1891$ & $0.009 \%$ & $0.21 \%$ & $0.003 \%$ & $0.098 \%$ \\
$1999-2014$ & $0.004 \%$ & $0.28 \%$ & $0.008 \%$ & $0.430 \%$ \\
\hline
\end{tabular}




\subsection{Interviews with Summer Farmers}

The twelve interviewed summer farmers were or had been part- or full-time farmers, several of them getting their income from farming supplemented with tourism, forestry, carpentry, park ranger occupation, etc. Animals kept varied; nine farmers kept cattle, seven farmers kept or had kept sheep, six farmers kept goats, some also kept a few pigs, horses and chickens. Products sold were milk, cheese, butter, pelts, tourist experiences (food, lodging etc.) and craft courses related to summer farming. Some farmers also had the production of biological and bio-cultural values as an important part of their income, since grazing at summer farms is compensated through the Swedish Rural Development Program [19] (Appendix A Table A1).

\subsubsection{Experience of Carnivore Encounters}

All informants had experienced bear attacks and six of the summer farmers in Dalarna also had experienced wolf attacks. The first bear attacks on livestock in our study took place in the 1980s (Appendix A Table A1). The wolf attacks started around the year 2000 (1997/1999, 2004, 2009, two in 2010).

All informants agree that sheep are most vulnerable to carnivore attacks. Some informants explain that they have the opportunity to leave their sheep at the home farm and thus have actively refrained from bringing sheep to the summer farms, in order not to lose them. Others have sold their sheep since they can no longer bring them to the summer farms.

"It is useless to bring sheep to the summer farm. They are so stupid-when they meet a bear they start running, but after a while they stop and look back to see if the bear is still there. The bear usually is!" (Summer farmer D, Jämtland).

"It was the presence of wolves that made us sell the animals. It was possible to get (permission for) protective hunting of bears but not of the wolves." (Summer farmer G in Dalarna).

Several informants noted significant secondary health impacts on their livestock that persisted after attacks, also on animals that were not touched by the carnivores. Commonly mentioned impacts were abortion of fetuses, animals not becoming pregnant, lower milk production, lower quality of milk, milk not curdling for cheese making etc. This, together with increasing costs and severe stress from searching for injured and scared livestock, have caused some of the interviewees to give up summer farming.

\subsubsection{Traditional Knowledge}

It is clear from the interviews that the summer farmers did not know beforehand how to handle carnivore attacks. None of the summer farmers had experience of carnivores on their summer farms or in the surroundings of the summer farms before the 1980s.

"There is no history of carnivores in the surroundings of our summer farm". (Summer farmer B, Dalarna).

Some informants had anecdotal references to carnivores in the past. One of the informants in Jämtland went to the elders in the village after the first bear attack and specifically asked about previous carnivore experience at the summer farms. They could find no such experience.

"There was no information, but once in the 1930s a horse came home injured by a bear. This was unique at that time". (Summer farmer B, Jämtland).

\subsubsection{New Knowledge and Preventive Measures}

However, the interviews point to emerging new knowledge about carnivores. Many of the farmers refer to their own experience and also to learning from other farmers.

"We who have had the problems (with carnivores) are the ones with most knowledge nowadays". (Summer farmer B, Dalarna).

Several informants have learned about carnivores from their own livestock. We were told that it is important to observe the animals and watch them, as especially the experienced livestock are more 
alert and change their behavior. For example if the wind allows it, the livestock can smell if there are carnivores around and determine whether they dare to leave the vicinity of the summer farm.

"I walked out with my goats. They didn't want to go in the direction I chose, but I made them go. Later that day there was an attack. One needs to listen to the animals". (Summer farmer C, Dalarna).

The differences in the behavior of livestock are useful in new ways, e.g., having "loud goats". Loudly bleating goats are easier to locate and they answer when the farmers call for them.

"To have goats at the summer farm that make a lot of noise is good because then you know where they are". (Summer farmer C, Dalarna).

Inexperienced animals are more easily depredated than animals with experience of attacks. The behavior of livestock changes after an attack. The farmers needed to adapt to changed behavior. For example after having experienced an attack, the livestock become easily scared and are harder to handle since they are worried and sometimes even aggressive. One summer farmer told us that after an attack, she has to wear the same clothes every day in order to come close to the goats for milking. She also has to be careful not to get hurt by their horns since the goats butt with their heads a lot when anxious.

"If the goats panic when we come, nothing works". (Summer farmer F, Dalarna).

A preventive measure used by many summer farmers today is keeping the animals indoors at night or in a night pen or corral. They also have pastures with carnivore-proof fences to use when there is high risk of attack. Others mentioned that they handle the livestock more, for instance by hugging them and thus making them smell of humans. Some summer farmers use bells on the livestock, both to scare off the carnivores and to locate the livestock. This is especially important if the livestock have encountered carnivores and are afraid to return to the summer farm in the afternoon. Nowadays the farmers sometimes use GPS collars to locate their livestock.

Several informants told us that the carnivores are not afraid of people. They feel as if the carnivores lie and wait for the livestock enter the forest.

"I do not believe in herding. The wolf attacked $30 \mathrm{~m}$ from my father in law who was armed. It took place in the dense contorta (Pinus contorta) plantation". (Summer farmer G, Dalarna).

"Nothing helped whatever we tried. The bear wasn't scared by us clanking pot lids, hooting the birch bark horn or throwing stones. It was completely unafraid and came nearer. We got help with carnivore-proof fencing around the corral. The bear stayed outside the fence. It mapped the routines of the animals and lay in wait along the road where it knew they would pass. The bears often attack during daytime". (Summer farmer A, Jämtland).

Most farmers felt that their knowledge was not valued by the authorities and they would like to have more dialogue with the county administrative boards. Several of the farmers had considered giving up their summer farming due to the increased pressure from predators. Quick help with protective hunting was pointed out as the most needed action by the authorities.

"It there is too much disturbance and too many injuries we might definitely give up.... We need quick help and full compensation. Predators are costly. If our cultural heritage is to be maintained these costs must be met". (Summer farmer C, Jämtland).

\section{Discussion}

\subsection{Depredation Rates}

Following intense hunting and near extinction, carnivores are now recolonizing lost grounds and increasing rapidly throughout Europe [3,62]. In Scandinavia the recolonization process has been especially pronounced since the 1990s $[2,8,33]$. By combining different numerical data, we can for the first time compare recent (since 1998) and historical depredation rates in two counties in Sweden. Recent depredation rates in Dalarna are higher than they were at the end of the nineteenth century while the opposite pattern is seen in Jämtland. Another difference between the counties is that recent depredation rates in Dalarna are twice the recent rates in Jämtland, contrary to the historical situation. 
It is noticeable that recent and historical depredation rates in fact are of the same order, despite many conditions for livestock husbandry having changed [14,16]. It is also noteworthy that there were no data on depredation from 1931 to 1998; during those years there was no interest from the authorities to note depredation. When the numbers of killed livestock increased there was again a need to keep data. The fact that the risk of having a cow or sheep killed in Dalarna is larger since the return of the carnivores, compared to well before they disappeared, entails a number of follow up questions on the factors determining depredation. The depredation rates are the result of the combined effect of several interconnected factors: number of carnivores, number of livestock and other available prey, and ability of farmers to prevent attacks and to protect their livestock. These will be discussed further below.

While there are no estimates of past carnivore population sizes available, the number of wolves and bears killed indicates that the historical period, 1876-1891, represents a time when large carnivores were present in numbers that warranted killing, although the trend clearly indicates diminishing populations (Figures 4 and 5). Although the historical number of carnivores killed cannot be compared directly with the recovering bear and wolf populations from 1999 to 2014, for which we have absolute numbers, the fact that the historical number of wolves killed year after year in Jämtland exceeded the total population numbers today clearly shows that the historical wolf population in Jämtland was larger than at present. Bounty data represent a combination of the number of available carnivores and hunting efforts. For instance, a Polish long-term comparison of wolf hunting data and population densities showed that during times of war and uprising, hunting efforts were lower, leading to a subsequent rise in wolf densities [39]. Other studies show that hunting results reflect estimated population numbers quite well [63,64]. In historical studies it is often necessary for comparisons to use data that are approximations, for example Kardell [12] examines the historical development of forest browsing since 1900 using numbers of livestock compared to numbers of moose shot. The historical records of numbers of carnivores killed are in accordance with studies suggesting that offering bounties led to the extinction of wolves [28,33] and near extinction of bears in Sweden [27,31]. In our data, a decline in the number of bears and wolves killed from 1876 onwards is accompanied by a simultaneous drop in the historical number of livestock killed, indicating that the historical killing data indeed reflect a decreasing carnivore population.

It is likely that the increased depredation rates in Dalarna are due to higher numbers of predators today compared to the historical period. We must also consider that the actual hunting pressure of carnivores on livestock is not only determined by carnivore numbers, but also by their access of other potential prey, which has changed through history. During the nineteenth century and earlier, livestock were the dominating prey for carnivores because there were few other prey species available. Carnivore population sizes may even have been limited by availability of prey in winter, since livestock were stabled and fed inside for seven months of the year [10,12]. Today the number of forest grazing livestock is low compared to e.g., the nineteenth century. On the other hand the historical populations of moose (Alces alces) and roe deer (Capreolus capreolus) were very small. They started to increase first after the 1950s when use of forest grazing with livestock had stopped [12] and the numbers of carnivores were low. Currently the main prey of wolves is moose, which is available all year round in Scandinavia $[65,66]$, indicating that higher carnivore numbers might be supported than was possible in the past.

The present size of the wolf population in Jämtland is in principle determined by regulations relating to Sami reindeer herding, which specifies that wolves interfering with the reindeer herding are moved to other areas or killed through protective hunting [36]. This contrasts to the situation in Dalarna where the wolf population has increased steadily since 1999, leading to 10 times more wolves than in Jämtland in only 60 per cent of the area. Jämtland, on the other hand, has about twice as many bears as Dalarna. Thus, the larger wolf population probably explains the high recent depredation rate in Dalarna. The differences between the two counties illustrate the strong effect of management on carnivore expansion in Sweden. The effect of management is also shown in Norway, where the 
Eurasian lynx population is regulated by a quota-regulated culling in accordance to changing policies and interests from various stakeholders, including sheep farmers [67].

Our study shows that sheep have been and are most vulnerable to depredation, both in the depredation data and according to information given by the farmers. The vulnerability of sheep is also confirmed by other studies: the depredation rate of bears on forest grazing cattle in Dalarna was 0.0007 per cent, in 2000-2006 [68], compared to a study focusing on sheep depredation in a wolf core area, where the depredation rate was 1 per cent [1]. A study from a bear conservation zone in Norway suggested replacing free-ranging sheep with cattle as the cattle mortality from depredation is 16 times lower than sheep mortality [69]. Another Norwegian study showed that free-ranging dairy cattle and bears did not use the same areas. The mechanisms behind this pattern remain unknown; their suggestion was that the cattle avoided bears and that bears avoided areas with people [70].

\subsection{Local and Traditional Knowledge of Protecting Livestock from Carnivores}

Although large parts of Swedish livestock husbandry have been modernized including that a majority of the livestock graze productive arable land [14], Swedish summer farmers continue to move their livestock seasonally to summer grazing areas, which is a basic characteristic they share with summer farmers from earlier generations [25]. Thus, the understanding of the environments at the grazing ground, free-ranging livestock behavior and livestock wellbeing can be seen as the result of a long-term adaptive process, i.e., local and traditional knowledge [45]. This is especially the case on summer farms since these are often inherited [18]. Swedish summer farmers can be seen as pockets of local and traditional knowledge, in the sense that their community remains true to their traditional ways, comparable to the Spanish farmers described by Gómez-Baggethun et al. [71]. Similar traditional pastoral knowledge in the Pyrenees has been described by Fernández-Giménez and Estaque [72] and from Hungary by Molnár [41,42]. Conditions at the summer farms have gone through substantial environmental changes through history, among others the decline and later increase of carnivores. While past summer-farmers (before carnivore extinction/reduction) had experienced a long-term relationship with carnivores and adopted strategies to minimize the risks of their presence [9], the long period with no or low numbers of carnivores lessened the risk and resulted in an erosion of knowledge of protecting strategies. For recent summer farmers, the increase in carnivores is a relatively new element with a great impact on livestock husbandry, and the summer farmers were not prepared for the returning threat. This is consistent with patterns observed in the rest of Europe, where carnivores decreased, only to increase again [7]. For example in Georgia (Caucasus), the damage from wolf attacks increased considerably after a 50 year break since traditional knowledge about how to protect the livestock was lost [40]. In Slovakia, the use of livestock-guarding dogs decreased when the wolves decreased, however when the wolves increased again the herds that had kept their guard dogs experienced 70 per cent less damage [73]. In Romania there are fewer incidents of depredation in areas with traditional livestock management than in areas with livestock that have had a discontinuous history of carnivores [5].

The absence of knowledge about carnivore protection at Swedish summer farms correspond well with results from studies on Spanish pastoralists, in which it was shown that when local and traditional knowledge of a particular task was not applied, it disappeared quickly [24,47,48]. Differences between our two studied Swedish counties highlight the effect of time on knowledge erosion. Summer farmers in Jämtland were aware of bears and had heard stories about livestock being attacked by bears, corresponding to the fact that the bear was never extinct [32]. The only summer farmers that learned about carnivores from their parents come from Jämtland. In contrast, summer farmers in Dalarna, where carnivores were absent for about 100 years, had heard no stories about carnivore encounters in their areas from earlier generations.

New local and traditional knowledge can evolve in response to changing environments and also merge with other existing forms of knowledge as part of the adaptive process, thus creating new and refined knowledge systems when needed $[41,42,48,71]$. In this study area, as the carnivores increased 
the summer farmers learned again to protect their livestock. The farmers learn from their livestock, for example to be aware of carnivore presence and avoid encounters. By talking to each other and sharing experiences, the summer farmers learn and create new local knowledge that may help to reduce future depredation risks. They see differences between breeds of livestock in, for example, their ability to detect carnivores and to defend themselves. Several of the farmers thus changed the breeds that they keep and do not bring sheep to summer farms anymore. Summer farmers have also learned about carnivore behavior, for example, in what environment they hide and their movements. There have been attacks close to the farms, where carnivores lie in wait for the livestock. Some of the old practices are difficult to employ again. For example, protective hunting is today only permitted under certain conditions and herding is at present not an option today for most summer farmers for economic reasons. Some of the interviewed farmers also pointed out that guard dogs are not safe with tourists or other people moving in the grazed forests. All these changes will with time change the environment around the summer farms which in turn will change the conditions for future summer farmers.

\subsection{Management of Livestock in Carnivore Areas}

Our study shows that the current carnivore-livestock conflict is similar to the conflict during the decades around 1900s, when it comes to depredation rates. However, there are several differences between the two studied time periods, for example the numbers of summer farms have declined and consequently the numbers of forest grazing livestock, the farmers receive money for producing bio-cultural values rather than traditional food production, and most notable is the historical shift in policy from hunting to protecting the carnivores. There are also differences regarding the preparedness of summer farmers to face the new challenges associated with an increasing carnivore population in their grazing areas. The knowledge about carnivore protection had eroded during the period with no or low numbers of carnivores. However, new knowledge developed when the carnivores returned. The interviews also showed that farming practices have changed as a result of increased carnivore populations during recent years.

Traditional knowledge holders have accumulated practically applied knowledge for centuries, and Makinson [74] argues that by adding local knowledge adapted to the local environment to scientific knowledge, gaps in basic scientific understanding can be bridged. It is a risky but necessary task to try to understand and integrate knowledge from many disciplines and experiences [13,49]. An enriched picture involving local and traditional knowledge can be used as a starting point together with specialist knowledge and expertise to improve future management planning [75-77]. Zimmermann et al. [78] showed that more experience and knowledge among different stakeholders increased understanding and reduced initial conflict in areas re-colonized by carnivores. This is important since the more intense a conflict, the less likely different stakeholders are to talk to each other $[4,79,80]$.

In conclusion, we expect that the situation for summer farmers will continue to be difficult due to the increasing carnivore populations but we also see opportunities and solutions based on application of traditional ecological knowledge and increased local governance. Clearly this is needed in order for the remaining summer farmers to continue and for this ancient tradition to persist and carry biodiversity and cultural legacies into the future. Our study can thus contribute to the discussion about effects of increasing carnivores on the conditions for free-ranging livestock husbandry. Furthermore, interdisciplinary and retrospective studies on livestock-carnivore conflicts can contribute to more sustainable solutions for future carnivore management and successful livestock husbandry in areas with increasing numbers of carnivores.

Acknowledgments: We are very grateful to the summer farmers who spent their valuable time participating in our interviews. We also wish to thank Viltskadecenter for providing us with unpublished material. Many thanks to Erik Axelsson who helped with the figures and Henrik Andrén for reviewing the carnivore data. This study was funded by the "Swedish Biodiversity Centre" and "Interreg Sverige-Norge-Grazing of outlying land: a biological cultural heritage as resource for a sustainable future 2011-2014". We also thank three reviewers for valuable comments on the manuscript. 
Author Contributions: Weronika Axelsson Linkowski and Marie Kvarnström initiated the interview study. Weronika Axelsson Linkowski together with Lars Östlund and Jon Moen developed the ideas for the manuscript. Anna Westin contributed with an agri-historical perspective. Weronika Axelsson Linkowski wrote the manuscript with support from the co-authors.

Conflicts of Interest: The authors declare no conflict of interest. The founding sponsors had no role in the design of the study; in the collection, analyses, or interpretation of data; in the writing of the manuscript, and in the decision to publish the results.

Ethical Statement: Following the ethical guidelines by the Swedish Research Council the respondents were carefully informed before the interviews about the purpose of the study and how the interviews were going to be used and all participants then voluntary agreed to participate in this research. 


\section{Appendix A}

Table A1. Experiences from carnivore encounters among the interviewed summer farmers. Id-code stands for farmer interviewed. The columns contain basic information about livestock kept and sources of income, year of first encountere with carnivores at the summer farm, observations on livestock behavior in response to carnivore presence and observations about carnivore behavior. The four right columns present which preventive actions summer farmers have taken, where they gained knowledge about preventive measures, proposals for future management and consequences following the presence of carnivores. $\mathrm{CAB}=\mathrm{County}$ Administrative Board.

\begin{tabular}{|c|c|c|c|c|c|c|c|c|c|}
\hline $\begin{array}{l}\text { Id-code Main } \\
\text { Occupation }\end{array}$ & LiveStock & $\begin{array}{l}\text { Products, Sources } \\
\text { of Income }\end{array}$ & $\begin{array}{c}\text { Carnivore } \\
\text { Encounters Since }\end{array}$ & $\begin{array}{l}\text { Behavior of Livestock } \\
\text { with Carnivores }\end{array}$ & $\begin{array}{c}\text { Behavior } \\
\text { Carnivores }\end{array}$ & $\begin{array}{l}\text { Actions to Prevent } \\
\text { Attacks }\end{array}$ & $\begin{array}{l}\text { Carnivore Knowledge, } \\
\text { Where From? }\end{array}$ & $\begin{array}{l}\text { Proposals for } \\
\text { Management }\end{array}$ & $\begin{array}{l}\text { Long Term Effects } \\
\text { of Carnivores }\end{array}$ \\
\hline \multicolumn{10}{|l|}{ Dalarna } \\
\hline $\begin{array}{c}\text { A } \\
\text { Farmer }\end{array}$ & $\begin{array}{l}40 \text { cattle, } 30 \text { sheep, } \\
12 \text { goats, chickens } \\
\text { pigs, horses }\end{array}$ & $\begin{array}{c}\text { Milk, meat, } \\
\text { bio-cultural values }\end{array}$ & $\begin{array}{l}\text { Bears 1995, } \\
\text { wolves 2004 }\end{array}$ & $\begin{array}{l}\text { Cows afraid and } \\
\text { aggressive, attack } \\
\text { humans. Break up in } \\
\text { small groups, hard to } \\
\text { find, avoid farm. Lower } \\
\text { milk production, poorer } \\
\text { quality. Lower fecundity. }\end{array}$ & $\begin{array}{l}\text { Wolves and bears } \\
\text { unafraid. Attack } \\
\text { any time. Seem to } \\
\text { know the area } \\
\text { around farm well. }\end{array}$ & $\begin{array}{l}\text { Keep livestock night } \\
\text { stabled. Teach them safe } \\
\text { paths. Remove carnivore } \\
\text { hiding places. Keep } \\
\text { experienced breeds. Salt } \\
\text { stone in safe area. }\end{array}$ & $\begin{array}{l}\text { From hunters, read old } \\
\text { books with stories } \\
\text { about carnivores. }\end{array}$ & $\begin{array}{l}\text { Quick protective } \\
\text { hunt. }\end{array}$ & $\begin{array}{l}\text { Stopped summer } \\
\text { farming, partly } \\
\text { because of } \\
\text { carnivores }\end{array}$ \\
\hline $\begin{array}{c}B \\
\text { Farmer }\end{array}$ & 65 cattle & $\begin{array}{l}\text { Meat, biological } \\
\text { values }\end{array}$ & $\begin{array}{r}\text { Bears 2002, } \\
\text { wolves 2012 }\end{array}$ & $\begin{array}{l}\text { Cattle observant, move in } \\
\text { tight groups, notice } \\
\text { presence of wolves at } \\
\text { once. Experienced cattle } \\
\text { show the others attack } \\
\text { sites. Lower fecundity. } \\
\text { Avoid certain areas, } \\
\text { results inloss of grazing. }\end{array}$ & $\begin{array}{l}\text { Wolves come } \\
\text { closer to farms } \\
\text { than many think, } \\
\text { tracks very close } \\
\text { to summer farm }\end{array}$ & $\begin{array}{l}\text { Timing of summer } \\
\text { grazing season to avoid } \\
\text { bears (not too early) and } \\
\text { wolves (not too late). } \\
\text { Night corrals. Put human } \\
\text { scent on livestock (but } \\
\text { wolves do not care) }\end{array}$ & $\begin{array}{l}\text { Own experience. } \\
\text { Information on fencing } \\
\text { from } C A B \text {, and Wildlife } \\
\text { Damage Centre. }\end{array}$ & $\begin{array}{l}\text { Quick protective } \\
\text { hunt More } \\
\text { dialogue } \\
\text { CAB_farmers. } \\
\text { Full } \\
\text { compensation for } \\
\text { extra costs. }\end{array}$ & \\
\hline $\begin{array}{c}\text { C } \\
\text { Goat farmer, } \\
\text { dairy worker, } \\
\text { projects }\end{array}$ & $\begin{array}{l}4 \text { cattle, } 3 \text { calves, } \\
32 \text { goats }\end{array}$ & $\begin{array}{c}\text { Meat, milk, cheese, } \\
\text { courses, biological } \\
\text { values }\end{array}$ & - & $\begin{array}{l}\text { Goats become watchful. } \\
\text { Important to have } \\
\text { experienced goats in } \\
\text { flock. Avoid dense } \\
\text { vegetation. }\end{array}$ & $\begin{array}{l}\text { Carnivores } \\
\text { intelligent, seem } \\
\text { to learn where } \\
\text { livestock go. }\end{array}$ & $\begin{array}{l}\text { Night stabling. Let goats } \\
\text { choose where to graze, } \\
\text { herding part of time. } \\
\text { Keep livestock that trust } \\
\text { me. Keep noisy goats. } \\
\text { Keeping calves at } \\
\text { farmstead and letting } \\
\text { calves suckle in afternoon } \\
\text { make cows come to farm. }\end{array}$ & $\begin{array}{l}\text { Information on fencing } \\
\text { from Wildlife Damage } \\
\text { Centre. }\end{array}$ & $\begin{array}{l}\text { Quick protective } \\
\text { hunt, GPS on } \\
\text { livestock. Access } \\
\text { to search dogs }\end{array}$ & \\
\hline $\begin{array}{c}\mathrm{D} \\
\text { Farmer }\end{array}$ & $\begin{array}{l}80 \text { sheep before, } \\
\text { now } 30-40 \text { cattle }\end{array}$ & $\begin{array}{l}\text { Meat, biological } \\
\text { values }\end{array}$ & $\begin{array}{l}\text { Bears since the } \\
\text { end of the 1980s }\end{array}$ & $\begin{array}{l}\text { Sheep easily killed, } \\
\text { surviving sheep have } \\
\text { lower fecundity. Cattle } \\
\text { flee long distances, } \\
\text { difficult to find. }\end{array}$ & $\begin{array}{l}\text { Bears took } 94 \\
\text { sheep, once one } \\
\text { bear took } 20 \\
\text { sheep. }\end{array}$ & $\begin{array}{l}\text { Night corral \& fenced } \\
\text { field. Stopped keeping } \\
\text { sheep and do not keep } \\
\text { calves at summer farm }\end{array}$ & Own experience. & $\begin{array}{l}\text { Quick protective } \\
\text { hunt }\end{array}$ & $\begin{array}{l}\text { Stopped keeping } \\
\text { sheep at summer } \\
\text { farm }\end{array}$ \\
\hline $\begin{array}{l}E \\
\text { Part-time } \\
\text { farmer }\end{array}$ & 120 sheep lambs & $\begin{array}{l}\text { Meat, wool, pelts, } \\
\text { biological values }\end{array}$ & $\begin{array}{c}\text { Bears 1995, } \\
\text { wolves 1997/1999 }\end{array}$ & $\begin{array}{l}\text { Livestock become shy, } \\
\text { watchful, do not eat } \\
\text { enough. Loss of } \\
\text { production. }\end{array}$ & $\begin{array}{l}\text { Wolves incredibly } \\
\text { effective, } \\
\text { unafraid, know } \\
\text { where to hide }\end{array}$ & $\begin{array}{l}\text { Night corral and electric } \\
\text { fences }\end{array}$ & $\begin{array}{l}\text { Own experience. } \\
\text { Information on fencing } \\
\text { from CAB. }\end{array}$ & $\begin{array}{l}\text { Quick protective } \\
\text { hunt }\end{array}$ & $\begin{array}{l}\text { Stopped summer } \\
\text { farming }\end{array}$ \\
\hline
\end{tabular}


Table A1. Cont.

\begin{tabular}{|c|c|c|c|c|c|c|c|c|c|}
\hline $\begin{array}{l}\text { Id-code Main } \\
\text { Occupation }\end{array}$ & LiveStock & $\begin{array}{l}\text { Products, Sources } \\
\text { of Income }\end{array}$ & $\begin{array}{c}\text { Carnivore } \\
\text { Encounters Since }\end{array}$ & $\begin{array}{l}\text { Behavior of Livestock } \\
\text { with Carnivores }\end{array}$ & $\begin{array}{l}\text { Behavior } \\
\text { Carnivores }\end{array}$ & $\begin{array}{l}\text { Actions to Prevent } \\
\text { Attacks }\end{array}$ & $\begin{array}{l}\text { Carnivore Knowledge, } \\
\text { Where From? }\end{array}$ & $\begin{array}{l}\text { Proposals for } \\
\text { Management }\end{array}$ & $\begin{array}{l}\text { Long Term Effects } \\
\text { of Carnivores }\end{array}$ \\
\hline \multicolumn{10}{|l|}{ Dalarna } \\
\hline $\begin{array}{c}\mathrm{F} \\
\text { Farmer, } \\
\text { forestry, } \\
\text { multiple areas } \\
\text { of income }\end{array}$ & $\begin{array}{c}23 \text { cattle plus } \\
\text { calves, } 30-35 \\
\text { goats, horses, pigs }\end{array}$ & $\begin{array}{l}\text { Milk, butter, cheese, } \\
\text { meat, bio-cultural } \\
\text { values }\end{array}$ & Wolves 2009 & $\begin{array}{l}\text { Swedish mountain cattle } \\
\text { breed and experienced } \\
\text { cows keep watch, wait } \\
\text { and smell before deciding } \\
\text { where to graze. Udder } \\
\text { inflammations, still-born } \\
\text { calves. Sheep clueless. }\end{array}$ & $\begin{array}{l}\text { Wolves move on } \\
\text { bogs, forest roads; } \\
\text { bears appear } \\
\text { anywhere; }\end{array}$ & $\begin{array}{c}\text { Livestock stabled at } \\
\text { night; GPS on livestock. } \\
\text { Carnivore safe fence at } \\
\text { home farm. }\end{array}$ & $\begin{array}{l}\text { Learnt from other } \\
\text { summer farmers with } \\
\text { experience. } \\
\text { Information on fencing } \\
\text { from CAB. }\end{array}$ & $\begin{array}{l}\text { Quick protective } \\
\text { hunt. Dogs are } \\
\text { not safe with } \\
\text { tourists. Pigs } \\
\text { might be tried as } \\
\text { watchdogs. }\end{array}$ & \\
\hline $\begin{array}{c}\mathrm{G} \\
\text { Farmer }\end{array}$ & $\begin{array}{l}7 \text { cattle, } 15 \text { sheep, } \\
\text { goats, horses }\end{array}$ & $\begin{array}{l}\text { Meat, household } \\
\text { milk, biological } \\
\text { values }\end{array}$ & $\begin{array}{l}\text { Bears 2000, Wolf } \\
2001\end{array}$ & $\begin{array}{l}\text { Only sheep have been } \\
\text { attacked, usually young } \\
\text { ewes, often with bells or } \\
\text { lambs of ewes with bells. }\end{array}$ & $\begin{array}{l}\text { Bears hide in } \\
\text { forest, use heights } \\
\text { for overview. } \\
\text { Wolf problem } \\
\text { ceased after } \\
\text { hunting. }\end{array}$ & $\begin{array}{l}\text { Animals stabled at night } \\
\text { and fences. Several large } \\
\text { bears have been shot. } \\
\text { Breeding male wolf was } \\
\text { killed and young wolf } \\
\text { killed earlier. }\end{array}$ & $\begin{array}{l}\text { Wildlife Damage } \\
\text { Centre, CAB, other } \\
\text { farmers. }\end{array}$ & $\begin{array}{l}\text { Quick protective } \\
\text { hunt. Herding } \\
\text { dogs are not safe } \\
\text { with tourists. }\end{array}$ & \\
\hline $\begin{array}{c}\mathrm{H} \\
\text { Goat farmer }\end{array}$ & 70 goats & Milk & Bears 2001 & $\begin{array}{l}\text { The goats stay close to } \\
\text { the farm. }\end{array}$ & $\begin{array}{l}\text { Bears close to } \\
\text { human homes }\end{array}$ & $\begin{array}{l}\text { Keeping livestock close } \\
\text { to farm }\end{array}$ & - & $\begin{array}{c}\text { Quick protective } \\
\text { hunt }\end{array}$ & \\
\hline \multicolumn{10}{|l|}{ Jämtland } \\
\hline $\begin{array}{c}\mathrm{A} \\
\text { Farmer }\end{array}$ & $\begin{array}{l}\text { 60-80 goats, } 36 \\
\text { sheep. }\end{array}$ & $\begin{array}{l}\text { Milk, cheese, meat, } \\
\text { pelts, courses, } \\
\text { bio-cultural values }\end{array}$ & Bears 2005 & $\begin{array}{l}\text { Goats become very } \\
\text { watchful, stay on high } \\
\text { terrain. Loss of milk and } \\
\text { fecundity, many still-born } \\
\text { the year after attack, } \\
\text { damaged udders. Cows } \\
\text { often still and listen. }\end{array}$ & $\begin{array}{c}\text { Bears hide in } \\
\text { dense vegetation } \\
\text { near farm, } \\
\text { unafraid. Bears } \\
\text { teach each other. }\end{array}$ & $\begin{array}{l}\text { Night shelter. Important } \\
\text { to study cow behavior. } \\
\text { Care when handling } \\
\text { goats to avoid injury } \\
\text { from their horns (started } \\
\text { to butt with their heads } \\
\text { after attacks) }\end{array}$ & $\begin{array}{l}\text { Other farmers, Wildlife } \\
\text { Damage Centre and } \\
\text { Järvzoo. No info from } \\
\text { CAB, police even when } \\
\text { asked for. }\end{array}$ & $\begin{array}{l}\text { Quick protective } \\
\text { hunt. Need for } \\
\text { livestock shelters } \\
\text { and acute help. }\end{array}$ & $\begin{array}{l}\text { Moved to new } \\
\text { summer farm }\end{array}$ \\
\hline $\begin{array}{c}\text { B } \\
\text { Milk farmer, } \\
\text { some tourism }\end{array}$ & 20 cattle & $\begin{array}{l}\text { Milk, cheese, meat, } \\
\text { eco-tourism }\end{array}$ & Bears 1995 & $\begin{array}{l}\text { Cows avoided certain } \\
\text { areas for a week or so } \\
\text { after attack, co-existed } \\
\text { with bear. Now a } \\
\text { different bear that } \\
\text { attacks cows. }\end{array}$ & $\begin{array}{l}\text { Some bears do not } \\
\text { attack, others do }\end{array}$ & $\begin{array}{l}\text { Livestock stabled at night. } \\
\text { Herd them out in the } \\
\text { morning. Carnivore } \\
\text { safe fence. Used to have } \\
\text { sheep at summer farm. }\end{array}$ & $\begin{array}{l}\text { Other farmers, Wildlife } \\
\text { Damage Centre, CAB. }\end{array}$ & $\begin{array}{l}\text { Quick protective } \\
\text { hunt. More } \\
\text { dialogue and } \\
\text { compensation. }\end{array}$ & $\begin{array}{l}\text { Stopped keeping } \\
\text { sheep at } \\
\text { summer farm }\end{array}$ \\
\hline $\begin{array}{c}\text { C } \\
\text { Wood worker, } \\
\text { sheep farmer }\end{array}$ & $\begin{array}{l}30 \text { cattle } 50 \text { sheep } \\
\text { horse, pigs, } \\
\text { chickens }\end{array}$ & $\begin{array}{l}\text { Milk, meat, } \\
\text { bio-cultural values, } \\
\text { knowledge }\end{array}$ & Bears 1995 & $\begin{array}{l}\text { Cattle avoid large area, } \\
\text { loss of grazing land. } \\
\text { Flock stressed, ran back } \\
\text { to summer farm on } \\
\text { some occasions }\end{array}$ & - & $\begin{array}{l}\text { Livestock kept stabled at } \\
\text { night. Sheep fenced with } \\
\text { electric carnivore safe } \\
\text { fences, used to roam free. }\end{array}$ & $\begin{array}{l}99 \% \text { from my parents, } \\
\text { and they from } \\
\text { their parents. }\end{array}$ & $\begin{array}{l}\text { More dialogue } \\
\text { and } \\
\text { compensation for } \\
\text { preventive } \\
\text { actions. }\end{array}$ & $\begin{array}{l}\text { Stopped letting } \\
\text { sheep roam free }\end{array}$ \\
\hline $\begin{array}{l}\mathrm{D} \\
\text { Milk farmer, } \\
\text { ranger, } \\
\text { tourism }\end{array}$ & $\begin{array}{l}\text { Cattle, goats, } \\
\text { chickens }\end{array}$ & $\begin{array}{l}\text { Milk, cheese, meat, } \\
\text { eco-tourism }\end{array}$ & $\begin{array}{c}\text { Long term yearly } \\
\text { bear encounter } \\
\text { but no attack, } \\
2011 \\
\text { probably wolf }\end{array}$ & $\begin{array}{l}2011 \text { cattle frightened in } \\
\text { new way, } 10 \text { cows lost } \\
\text { calves Considerable milk } \\
\text { loss. Probably wolf. }\end{array}$ & $\begin{array}{l}\text { Bear passes in } \\
\text { July every year, } \\
\text { peaceful } \\
\text { co-existence } \\
\text { with cows }\end{array}$ & $\begin{array}{l}\text { Livestock fenced, stabled } \\
\text { at night. }\end{array}$ & $\begin{array}{l}\text { In training for park } \\
\text { ranger, additional } \\
\text { courses Swedish } \\
\text { Environmental } \\
\text { Protection Agency }\end{array}$ & $\begin{array}{l}\text { Quick protective } \\
\text { hunt, spring hunt } \\
\text { on bears. }\end{array}$ & $\begin{array}{l}\text { Stopped keeping } \\
\text { sheep at } \\
\text { summer farm }\end{array}$ \\
\hline
\end{tabular}




\section{References}

1. Liberg, O.; Aronson, Å.; Brainerd, S.M.; Karlsson, J.; Pedersen, H.-C.; Sand, H.; Wabakken, P. The recolonizing Scandinavian Wolf population: Research and management in two countries. In The World of Wolves: New Perspectives on Ecology, Behaviour and Management; Musiani, M., Boitani, L., Paquet, P.C., Eds.; University of Calgary Press: Calgary, AB, USA, 2010.

2. Sand, H.; Liberg, O.; Flagstad, Ø.; Wabakken, P.; Åkesson, M.; Karlsson, J.; Ahlqvist, P. Den Skandinaviska Vargen-En Sammanställning av Kunskapsläget Från det Skandinaviska Vargforskningsprojektet SKANDULV 1998-2014, Grimsö Forskningsstation, SLU; Rapport till Direktoratet for Naturforvaltning, Trondheim, Norge. 2014. (In Swedish). Available online: https:/ / www.regjeringen.no/globalassets/upload/kld/kl/klima-ogskogprosjektet/skandulv.pdf (accessed on 9 August 2017).

3. Chapron, G.; Kaczensky, P.; Linnell, J.D.C.; von Arx, M.; Huber, D.; Andren, H.; Vicente Lopez-Bao, J.; Adamec, M.; Alvares, F.; Anders, O.; et al. Recovery of large carnivores in Europe's modern human-dominated landscapes. Science 2014, 346, 1517-1519. [CrossRef] [PubMed]

4. Bisi, J.; Kurki, S.; Svensberg, M.; Liukkonen, T. Human dimensions of wolf (Canis lupus) conflicts in Finland. Eur. J. Wildl. Res. 2007, 53, 304-314. [CrossRef]

5. Dorresteijn, I.; Hanspach, J.; Kecskes, A.; Latkova, H.; Mezey, Z.; Sugar, S.; von Wehrden, H.; Fischer, J. Human-carnivore coexistence in a traditional rural landscape. Landsc. Ecol. 2014, 29, 1145-1155. [CrossRef]

6. Kojola, I.; Aspi, J.; Hakala, A.; Heikkinen, S.; Ilmoni, C.; Ronkainen, S. Dispersal in an expanding wolf population in Finland. J. Mammal. 2006, 87, 281-286. [CrossRef]

7. Zlatanova, D.; Ahmed, A.; Valasseva, A.; Genov, P. Adaptive Diet Strategy of the Wolf (Canis lupus L.) in Europe: A Review. Acta Zool. Bulg. 2014, 66, 439-452.

8. Kaartinen, S.; Luoto, M.; Kojola, I. Carnivore-livestock conflicts: Determinants of wolf (Canis lupus) depredation on sheep farms in Finland. Biodivers. Conserv. 2009, 18, 3503-3517. [CrossRef]

9. Kardell, Ö. Om Rödluvan och vargen och den svenska vargdebatten. RIG Kult. Tidskr. 2008, 91. (In Swedish, with English summary). Available online: journals.lub.lu.se/index.php/rig/article/download/3742/3494 (accessed on 13 September 2017).

10. Kardell, Ö.; Dahlström, A. Wolves in the Early Nineteenth-Century County of Jönköping, Sweden. Environ. Hist. 2013, 19, 339-370. [CrossRef]

11. Myrdal, J. Boskapsskötseln under Medeltiden; En källpluralistisk studie; Nordiska Museets Förlag: Stockholm, Sweden, 2012. (In Swedish)

12. Kardell, Ö. Swedish Forestry, Forest Pasture Grazing by Livestock, and Game Browsing Pressure since 1900. Environ. Hist. 2016, 22, 561-587. [CrossRef]

13. Simmons, I.G. The world scale. Environ. Hist. 2004, 10, 531-536. [CrossRef]

14. Myrdal, J.; Morell, M. (Eds.) The Agrarian History of Sweden. From 4000 BC to AD 2000; Nordic Academic Press: Lund, Sweden, 2011.

15. Bele, B.; Norderhaug, A. Traditional land use of the boreal forest landscape: Examples from Lierne, Nord-TrOndelag, Norway. Norsk Geogr. Tidsskr.-Nor. J. Geogr. 2013, 67, 12-23. [CrossRef]

16. Larsson, J. The expansion and Decline of a Transhumance system in Sweden, 1550-1920. Hist. Agrar. Revis. Agric. Hist. Rural 2012, 56, 11-39.

17. Nyrén, U. Från utrotning till utbredning. Den svenska vargstammen som historiskt allmoge- och överhetsprojekt. Hist. Tidskr. 2012, 123, 365-391. (In Swedish with English summary)

18. Hedén, A.-C. Fäbodnäringens Förutsättningar i Sverige. Utvärdering av Fäbodbruk, Fäboddrift och Utmarksbetet $i$ Landsbygdsprogrammet 2007-2013; Länsstyrelsen Dalarnas län: Falun, Sweden, 2014. (In Swedish)

19. Government Offices of Sweden. Sweden-Rural Development Programme (National) 2014-2020; Government Offices of Sweden: Stockholm, Sweden, 2016. (In Swedish). Available online: http:/ / www.jordbruksverket. se/download/18.229ea55815233ba0390e8c59/1452694447806/Landsbygdsprogrammet+2014--2020.pdf (accessed on 9 August 2017).

20. Austrheim, G.; Olsson, E.G.A.; Grontvedt, E. Land-use impact on plant communities in semi-natural sub-alpine grasslands of Budalen, central Norway. Biol. Conserv. 1999, 87, 369-379. [CrossRef]

21. Austrheim, G.; Eriksson, O. Recruitment and life-history traits of sparse plant species in subalpine grasslands. Can. J. Bot.-Rev. Can. Bot. 2003, 81, 171-182. [CrossRef] 
22. Olsson, E.G.A.; Austrheim, G.; Grenne, S.N. Landscape change patterns in mountains, land use and environmental diversity, Mid-Norway 1960-1993. Landsc. Ecol. 2000, 15, 155-170. [CrossRef]

23. Olsson, E.G.A.; Hanssen, S.; Rønningen, K. Different conservation values of biological diversity? A case study from the Jotunheimen mountain range, Norway. Norsk Geogr. Tidsskr. Nor. J. Geogr. 2004, 58, $204-212$. [CrossRef]

24. Rodriguez-Ortega, T.; Oteros-Rozas, E.; Ripoll-Bosch, R.; Tichit, M.; Martin-Lopez, B.; Bernues, A. Applying the ecosystem services framework to pasture-based livestock farming systems in Europe. Animal 2014, 8 , 1361-1372. [CrossRef] [PubMed]

25. Tunon, H.; Axelsson Linkowski, W.; Kvarnström, M.; Wissman, J.; Bele, B.; Norderhaug, A. To view a landscape: Reflections upon the governance of Scandinavian transhumance. Balt. World 2013, VI, 53-60.

26. Wilson, D.E.; Mittermeier, R.A. (Eds.) Handbook of the Mammals of the World-Volume 1; Lynx Edicions: Barcelona, Spain, 2009.

27. Lönnberg, E. Björnen i Sverige 1856-1928; Almqvist \& Wiksell: Uppsala/Stockholm, Sweden, 1929. (In Swedish)

28. Lönnberg, E. Bidrag till Vargens Historia i SVERIGE. In Kungl. Svenska Vetenskapsakademiens Skrifter $i$ Naturskyddsärenden; Svenska Vetenskapsakademiens: Stockholm, Sweden, 1934. (In Swedish)

29. Anon. Inventering av lodjur 2015. Bestandsstatus för Stora Rovdjur i Skandinavien 2-2015; Rovdata, Trondheim, Norway and Viltskadecenter: Grimsö, Sweden, 2015. (In Swedish). Available online: http:/ / www.nina.no/ archive/nina/PppBasePdf/Bestandsstatus\%20for\%20store\%20rovdyr\%20i\%20Skandinavia/2-2015.pdf (accessed on 9 August 2017).

30. Brøseth, H.; Eklund, A. (Eds.) Inventering av Järv 2015. Bestandsstatus för Stora Rovdjur i Skandinavien 3-2015; Rovdata, Trondheim, Norway and Viltskadecenter: Grimsö, Sweden, 2015. (In Swedish). Available online: https:/ / brage.bibsys.no/xmlui/handle/11250/2375476 (accessed on 13 September 2017).

31. Swenson, J.E.; Wabakken, P.; Sandegren, F.; Bjärvall, A.; Franzén, R.; Söderberg, A. The near extinction and recovery of brown bears in Scandinavia in relation to the bear management policies of Norway and Sweden. Wildl. Biol. 1995, 1, 11-25.

32. Kindberg, J.; Swenson, J.E. Björnstammens Storlek i Sverige 2013—Länsvisa Skattningar och Trender; Rapport 2014-2 Från Det Skandinaviska Björnprojektet. 2014. (In Swedish). Available online: http:/ /bearproject.info/ wp-content/uploads/2015/11/2014-E121-2-Bj\%C3\%B6rnstammens-storlek-i-Sverige-2013.pdf (accessed on 9 August 2017).

33. Wabakken, P.; Sand, H.; Liberg, O.; Bjärvall, A. The recovery, distribution, and population dynamics of wolves on the Scandinavian peninsula, 1978-1998. Can. J. Zool. 2001, 79, 710-725. [CrossRef]

34. Anon. Inventering av Varg Vintern 2014-2015. Inventeringsresultat för Stora Rovdjur i Skandinavien 1-2015; Rovdata og Viltskadecenter: Evenstad, Norway and Grimsö, Sweden, 2015. (In Swedish)

35. Wabakken, P.; Svensson, L.; Maartmann, E.; Åkesson, M.; Flagstad, Ø. Beståndsovervåkning av ulv Vinteren 2015-2016. Beståndsstatus for Store Rovdyr i Skandinavia 1-2016. Rovdata Evenstad, Norway and Viltskadecenter: Grimsö, Sweden, 2016. (In Norwegian and Swedish). Available online: http:/ /hdl.handle. net/11250/2390916 (accessed on 9 August 2017).

36. Proposition 2012/13:191. En Hållbar Rovdjurspolitik. (Governmental Bill 2012/13:191. A Sustainable Predator Policy). (In Swedish). Available online: http://www.regeringen.se/contentassets/ af7ef44fdcb8410bbadbbd117e033ced/en-hallbar-rovdjurspolitik-prop.-201213191 (accessed on 9 August 2017).

37. SOU 2012:22 Mål för Rovdjuren (Government Official Investigation 2012:22). (In Swedish). Available online: http: / / www.regeringen.se/49bba8 / contentassets /0b53f6bc5d98440e94767dbe37c59a0b / mal-forrovdjuren-sou-201222-hela (accessed on 29 August 2017).

38. Sahlén, V.; Swenson, J.; Brunberg, S.; Kindberg, J. Björnen i Sverige. En Rapport Från Skandinaviska Björnprojektet till den Svenska Rovdjursutredningen; Skandinaviska Björnprojektet Rapport 2006-4. 2006. (In Swedish). Available online: http://www.naturogat.se/rovdjur_pdf/060401_bjornen_i_sverige.pdf (accessed on 9 August 2017).

39. Jedrzejewska, B.; Jedrzejewski, W.; Bunevich, A.N.; Milkowski, L.; Okarma, H. Population dynamics of wolves Canis lupus in Bialowieza primeval forest (Poland and Belarus) in relation to hunting by humans, 1847-1993. Mamm. Rev. 1996, 26, 103-126. [CrossRef]

40. Kikvidze, Z.; Tevzadze, G. Loss of traditional knowledge aggravates wolf-human conflict in Georgia (Caucasus) in the wake of socio-economic change. Ambio 2015, 44, 452-457. [CrossRef] [PubMed] 
41. Molnár, Z. Traditional Ecological Knowledge of Herders on the Flora and Vegetation of the Hortobágy; Hortobágy Természetvédelmi Közalapítvány: Debrecen, Hungary, 2012.

42. Molnár, Z.; Kis, J.; Vadász, C.; Papp, L.; Sándor, I.; Béres, S.; Sinka, G.; Varga, A. Common and conflicting objectives and practices of herders and nature conservation managers: The need for a conservation herder. Ecosyst. Health Sustain. 2016, 2, e01215. [CrossRef]

43. Österling, P.A. Dialekt och folkminnesarkivens material—Etnologi på Institutet för språk och folkminnen (SOFI) exemplet ULMA. In Nycklar till Kunskap. Om Människans Bruk av Naturen; Tunon, H., Dahlström, A., Eds.; Centrum för Biologisk Mångfald: Uppsala Sweden; Kungl, Skogs-och Lantbruksakademien: Stockholm, Sweden, 2010; pp. 59-66. (In Swedish)

44. Berkes, F.; Colding, J.; Folke, C. Rediscovery of traditional ecological knowledge as adaptive management. Ecol. Appl. 2000, 10, 1251-1262. [CrossRef]

45. Food and Agriculture Organization of the United Nations. What is local knowledge? In Building on Gender, Agrobiodiversity and Local Knowledge; FAO: Rome, Italy, 2004; pp. 7-13. Available online: http:/ / www.fao.org/ docrep/013/i2050e/i2050e.pdf (accessed on 13 September 2017).

46. International Council for Science/Conseil International pour la Science March. Science and Traditional Knowledge and Sustainable Development; ICSU Series on Science for Sustainable Development. No. 4. 2002. Available online: http:/ / unesdoc.unesco.org/images/0015/001505/150501eo.pdf (accessed on 9 August 2017).

47. Gómez-Baggethun, E.; Reyes-García, V. Reinterpreting Change in Traditional Ecological Knowledge. Hum. Ecol. 2013, 41, 643-647. [CrossRef] [PubMed]

48. Oteros-Rozas, E.; Ontillera-Sanchez, R.; Sanosa, P.; Gómez-Baggethun, E.; Reyes-Garcia, V.; Gonzalez, J.A. Traditional ecological knowledge among transhumant pastoralists in Mediterranean Spain. Ecol. Soc. 2013, 18, 33. [CrossRef]

49. Winiwarter, V.; Armiero, M.; Van Dam, P.; Dix, A.; Eliasson, P.; Holm, P.; Jelečk, L.; Lambert, R.A.; Massard-Guilbaud, G.; De Molina, M.G.; et al. Environmental History in Europe from 1994 to 2004: Enthusiasm and Consolidation. Environ. Hist. 2004, 10, 501-530. [CrossRef]

50. Skogsstyrelsen/Statens domäner. Bidrag till Sveriges Officiella Statistik. Q Skogsväsendet 1870-1910; Norstedt \& Söner: Stockholm, Sweden, 1872-1912. (In Swedish)

51. Kungliga Domänstyrelsens Förvaltning. 1911-1965; Sveriges Officiella Statistik. Kungl. Domänstyrelsen; Norstedt \& Söner: Stockholm, Sweden, 1912-1966. (In Swedish)

52. Khalil, H.; Pasanen-Mortensen, M.; Elmhagen, B. The relationship between wolverine and larger predators, lynx and wolf, in a historical ecosystem context. Oecologia 2014, 175, 625-637. [CrossRef] [PubMed]

53. Persson, J.H.; Sand, H. Vargen: Viltet, Ekologin och Människan; Brittas, R., Ed.; Svenska Jägareförbundet: Spånga, Sweden, 1998. (In Swedish)

54. Viltskadecenter. 1998-2014. Varg i Skandinavien (Wolf in Scandinavia). Rovdata and Viltskadecenter: Evenstad, Norge; SLU: Grimsö, Sverige, 1999-2015. Available online: http:/ /www.viltskadecenter.se/index. php?option=com_content\&task=view\&id=110\&Itemid=881 (accessed on 9 August 2017).

55. Hushållningssällskapen. Bidrag till Sveriges officiella statistik. N, Jordbruk och Boskapsskötsel, 1865-1911; Norstedt \& Söner: Stockholm, Sweden, 1867-1912.

56. Statistiska Centralbyrån. Sveriges Officiella Statistik. 1913-1963. Jordbruk och Boskapsskötsel; Statistiska CentralbyråN: Stockholm, Sweden, 1916-1964. (In Swedish)

57. Jordbruksverket and Statistiska Centralbyrån. Jordbruksstatistisk Årsbok 1965-2000 (Statistical Yearbook of Agriculture); Jordbruksverket and Statistiska Centralbyrån: Jönköping, Sweden, 1965-2000. (In Swedish)

58. Jordbruksverket and Statistiska Centralbyrån. Jordbruksstatistisk Årsbok 2001-2014; Jordbruksverket and Statistiska centralbyrån: Jönköping, Sweden, 2001-2014. (In Swedish)

59. Viltskadecenter. Viltskadestatistik 2003-2014. (Statistics of Damage Caused by Wildlife; Wildlife Damage Centre: Riddarhyttan, Sweden, 2004-2015. (In Swedish). Available online: http:/ /www.viltskadecenter.se/index. php?option=com_content\&task=view\&id=110\&Itemid=881\#publikationervarg (accessed on 9 August 2017).

60. Morell, M. Jordbruket $i$ Industrisamhället; Natur och Kultur; LTs Förlag: Stockholm, Sweden, 2001. (In Swedish)

61. Flygare, I.A.; Isacson, M. Jordbruket $i$ Välfärdssamhället; Natur och Kultur; LTs Förlag: Örebro, Sweden, 2003. (In Swedish)

62. Vicente Lopez-Bao, J.; Kaczensky, P.; Linnell, J.D.C.; Boitani, L.; Chapron, G. Carnivore coexistence: Wilderness not required. Science 2015, 348, 871-872. [CrossRef] [PubMed] 
63. Hacquebord, L. Three Centuries of Whaling and Walrus hunting in Svalbard and its Impact on the Arctic Ecosystem. Environ. Hist. 2001, 7, 169-185. [CrossRef]

64. Lelli, B.; Harris, D.E.; Aboueissa, A.-M. Seal Bounties in Maine and Massachusetts, 1888 to 1962. Northeast. Nat. 2009, 16, 239-254. [CrossRef]

65. Wikenros, C.; Sand, H.; Bergström, R.; Liberg, O.; Chapron, G. Response of Moose Hunters to Predation following Wolf Return in Sweden. PLoS ONE 2015, 10. [CrossRef] [PubMed]

66. Zimmermann, B.; Sand, H.; Wabakken, P.; Liberg, O.; Andreassen, H.P. Predator-dependent functional response in wolves: From food limitation to surplus killing. J. Anim. Ecol. 2015, 84, 102-112. [CrossRef] [PubMed]

67. Linnell, J.D.C.; Broseth, H.; Odden, J.; Nielsen, E.B. Sustainably harvesting a large carnivore? Development of Eurasian lynx populations in Norway during 160 years of shifting policy. Environ. Manag. 2010, 45, 1142-1154. [CrossRef] [PubMed]

68. Lidberg, J. Slutrapport Från Projektet Fäbodbete och Rovdjur i Dalarna. Miljövårdsenheten Rapport 2007:15; Länsstyrelsen i Dalarnas län: Falun, Sweden, 2007. (In Swedish)

69. Zimmermann, B.; Wabakken, P.; Dötterer, M. Brown Bear-Livestock Conflicts in a Bear Conservation Zone in Norway: Are Cattle a Good Alternative to Sheep? Ursus 2003, 14, 72-83.

70. Steyaert, S.; Stoen, O.G.; Elfström, M.; Karlsson, J.; Van Lammeren, R.; Bokdam, J.; Zedrosser, A.; Brunberg, S.; Swenson, J.E. Resource selection by sympatric free-ranging dairy cattle and brown bears Ursus arctos. Wildl. Biol. 2011, 17, 389-403. [CrossRef]

71. Gómez-Baggethun, E.; Corbera, E.; Reyes-García, V. Traditional Ecological Knowledge and Global Environmental Change: Research findings and policy implications. Ecol. Soc. 2013, 18, 72. [CrossRef] [PubMed]

72. Fernández-Giménez, M.E.; Estaque, F.F. Pyrenean Pastoralists' Ecological Knowledge: Documentation and Application to Natural Resource Management and Adaptation. Hum. Ecol. 2012, 40, 287-300. [CrossRef]

73. Rigg, R.; Findo, S.; Wechselberger, M.; Gorman, M.L.; Sillero-Zubiri, C.; Macdonald, D.W. Mitigating carnivore-livestock conflict in Europe: Lessons from Slovakia. Oryx 2011, 45, 272-280. [CrossRef]

74. Mackinson, S. Integrating local and scientific knowledge: An example in fisheries science. Environ. Manag. 2001, 27, 533-545. [CrossRef]

75. Hernández-Morcillo, M.; Hoberg, J.; Oteros-Rozas, E.; Plieninger, T.; Gómez-Baggethun, E.; Reyes-Garcia, V. Traditional Ecological Knowledge in Europe Status Quo and Insights for the Environmental Policy Agenda. Environment 2014, 56, 3-17. [CrossRef]

76. Kis, J.; Barta, S.; Elekes, L.; Engi, L.; Fegyver, T.; Kecskeméti, J.; Lajkó, L.; Szabó, J. Traditional herders' knowledge and worldview and their role in managing biodiversity and ecosystem services of extensive pastures. In Indigenous and Local Knowledge of Biodiversity and Ecosystem Services in Europe and Central Asia; Knowledges of Nature 9; Roué, M., Molnár, Z., Eds.; UNESCO: Paris, France, 2016; pp. 57-71. Available online: http:/ / climatefrontlines.org/sites /default/files/ipbes/IPBES_in_Europe_and_Central_Asia_2016. pdf (accessed on 9 August 2017).

77. Sutherland, W.J.; Gardner, T.A.; Haider, L.J.; Dicks, L.V. How can local and traditional knowledge be effectively incorporated into international assessments? Oryx 2014, 48, 1-2. [CrossRef]

78. Zimmermann, B.; Wabakken, P.; Dötterer, M. Human-carnivore interactions in Norway: How does the re-appearance of large carnivores affect people's attitudes and levels of fear? For. Snow Landsc. Res. 2001, 76, 137-153.

79. Cinque, S. I Vargens Spår. Myndigheternas Handlingsutrymme i Förvaltning av Varg. Ph.D. Thesis, School of Public Administration and University of Gothenburg, Gothenburg, Sweden, 2008. (In Swedish with English summary)

80. Rondinini, C.; Boitani, L. Systematic conservation planning and the cost of tackling conservation conflicts with large carnivores in Italy. Conserv. Biol. 2007, 21, 1455-1462. [CrossRef] [PubMed]

(C) 2017 by the authors. Licensee MDPI, Basel, Switzerland. This article is an open access article distributed under the terms and conditions of the Creative Commons Attribution (CC BY) license (http://creativecommons.org/licenses/by/4.0/). 